\title{
Kinetics of Fly Ash Beneficiation by Carbon Burnout
}

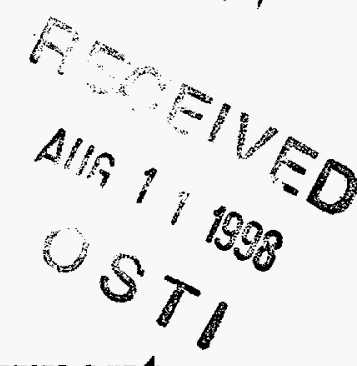

\section{Quarterly Report}

July 1 - September 30, 1997

Work Performed Under Contract No.: DE-FG22-94MT94016

For

U.S. Department of Energy

Office of Fossil Energy

Federal Energy Technology Center

P.O. Box 880

Morgantown, West Virginia 26507-0880

By

University of Maryland Eastern Shore

Energy Laboratory

Department of Natural Sciences

Princess Anne, Maryland 21853

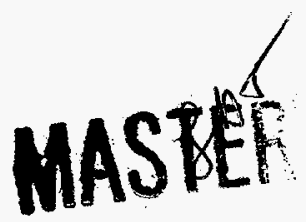




\section{Disclaimer}

This report was prepared as an account of work sponsored by an agency of the United States Government. Neither the United States Government nor any agency thereof, nor any of their employees, makes any warranty, express or implied, or assumes any legal liability or responsibility for the accuracy, completeness, or usefulness of any information, apparatus, product, or process disclosed, or represents that its use would not infringe privately owned rights. Reference herein to any specific commercial product, process, or service by trade name, trademark, manufacturer, or otherwise does not necessarily constitute or imply its endorsement, recommendation, or favoring by the United States Government or any agency thereof. The views and opinions of authors expressed herein do not necessarily state or reflect those of the United States Government or any agency thereof. 


\section{DISCLAIMER}

Portions of this document may be illegible electronic image products. Images are produced from the best available original document. 


\section{ABSTRACT}

OBJECTIVE

To investigate the kinetics of beneficiation of fly ash by carbon burnout The project is a joint venture between Delmarva Power, a power generating company on the eastern shore of Maryland, and the University of Maryland Eastern Shore. The studies have focused on the beneficiation of fly ash by carbon burnout.

\section{WORK DONE AND CONCLUSIONS}

This summer our efforts were directed toward collecting more Kinetic data and investigating oxidation behavior using varying oxygen concentration. We began to put together an interim report of the project activity to date. The interim report is arranged in a presentation format and is to be used as educational material for our graduate students. The full report will take the usual format when completed. The presentation format is enclosed with this report.

\section{SIGNIFICANCE TO FOSSIL ENERGY PROGRAM}

Project is related to Advanced Environmental Control Technology for Coal and coal residue.

\section{PLANS FOR NEXT OUARTER}

Our efforts will continue in the direction of investigation the carbon burnout of the fly ash and establishing a lower limit for the carbon remaining after burn out. We expect that the different concentrations of reactant gas will assist in this endeavor.

\section{HIGHLIGHT OF ACCOMPLISHMENTS}

- Introduction of a number of minority students to research experience in fossil energy.

- Successful application of Proportionality Law to kinetic data.

- Development of fossil energy instructional material for the class room. 


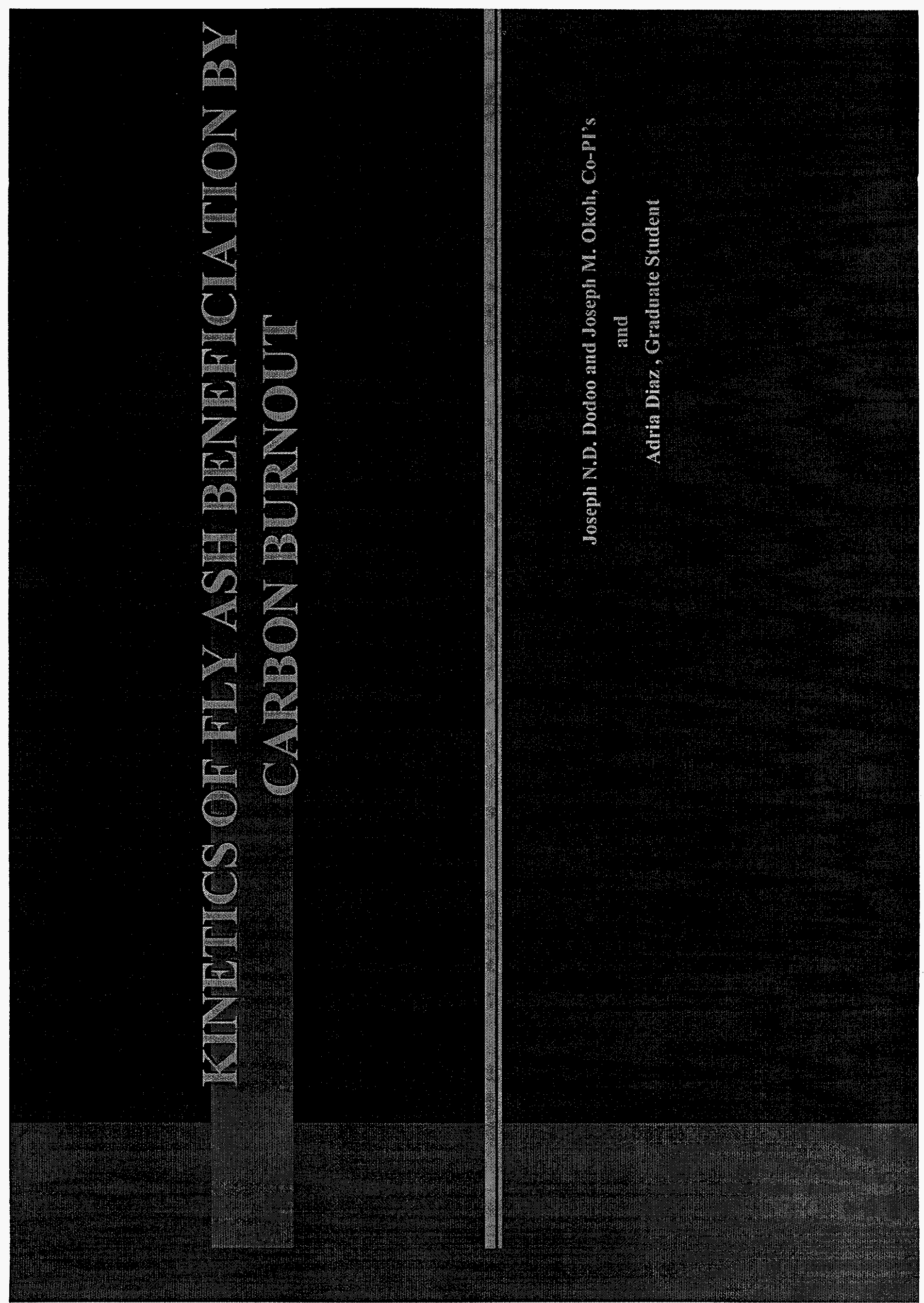


The material presented here provides information on the kinetics of coal fly ash as it is heated under a controlled environment. Fly ash is the residue that is produced when coal is burned. Typically, the coal is pulverised and burned in very large industrial burners. Massive amounts of heat is converted during the process and the ash that flies off the chute is generally collected by means of an electrostatic separator. As heat is applied to any carbon containing substance the substance loses weight as the carbon burns off. One could be forgiven for assuming that when large quantities of heat have been extracted from coal particles as small as $30-50 \mu \mathrm{m}$, the fly ash resulting from this process should be carbon free. Not so. There still remain measurable amounts of carbon. The carbon still remaining in the coal when all useful heat has been extracted from it is referred to as residual carbon. Amounts of residual carbon up to $12 \%$ are possible and in the present work we had analysis carried out which indicated that some of our samples did contain this amount of carbon. The fact that flash can be burned is proof of the presence of carbon, for during combustion it is the carbon in a material that is burned. How much of the residual carbon is ultimately burned depends on such factors as, pressure, oxidizing medium and the temperature inside the combusting chamber. The physical and chemical changes that a substance experiences when undergoing combustion is referred to as kinetics. We have presented the results of our experiment as view graphs. As such several of the materials are in abbreviated form. However, more details will be given during presentation. Quite naturally, the full report will contain the complete text. We hope that at the end of the seminar series the student will have gained some fundamental knowledge of the nature of coal fly ash and the process of reducing the residual carbon in the fly ash. 


\begin{abstract}
Oxidation Studies of coal fly ash have been carried out at partial pressures in the range 1 atmosphere down to 400 torr. The studies have also been carried out at 1 atmosphere for different temperatures in the range 500 to $750 \mathrm{oC}$. The equipment used was a state of the art Cann Theromogravimetric analyzer having sensitive microbalance that permitted measurements to $.1 \mu \mathrm{g}$. The analyzer is part of a GC/MS/TG setup in our laboratory. The fly ash was supplied by Delmarva Power Indian River Plant, DE. The samples were dried and stored in a desiccator to ensure that they remained dry prior to combustion. The combustion process inside the TGA is continuous and the heat released can be related to the percent of carbon consumed. Our setup provided easy identification of the elements in the fly ash. The elemental analysis was also augmented by use of an energy dispersive X-ray analyzer. In the X-ray analysis the carbon in the fly ash was compared with that in a dolomite $\{\mathrm{CaMg}(\mathrm{CO} 3) 2\}$ standard obtained from the U.S. Bureau of Mines (USBOM). Preliminary data show encouraging results in the rate of reduction of the residual carbon. Both analyses show reduction of carbon after burning.
\end{abstract}




\section{FLY ASH PRODUCTION AND DISPOSAL}

* Fly ash-byproduct of coal combustion

* Major constituents of fly ash

-Quartz $\left(\mathrm{SiO}_{2}\right)$

-Mullite $\left(3 \mathrm{Al}_{2} \mathrm{O}_{3} \cdot 2 \mathrm{SiO}_{2}\right)$

-Hematite $\left(\mathrm{Fe}_{2} \mathrm{O}_{3}\right)$

-Magnetite $\left(\mathrm{Fe}_{3} \mathrm{O}_{4}\right)$

-Lime $(\mathrm{CaO})$

-Gypsum $\left(\mathrm{CaSO}_{4} \cdot 2 \mathrm{H}_{2} \mathrm{O}\right)$

$*$ ASTM-Class C and Class F fly ash 


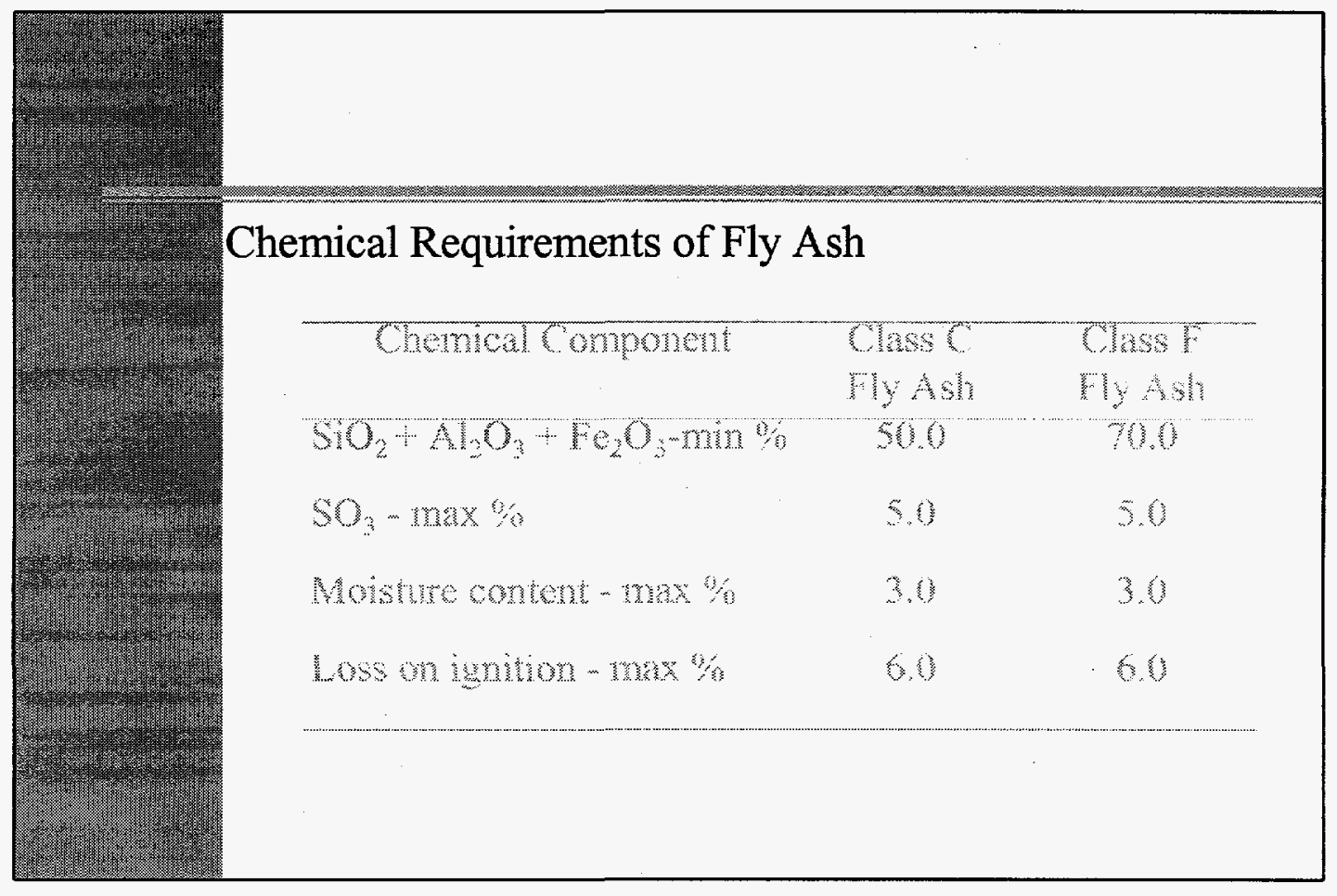




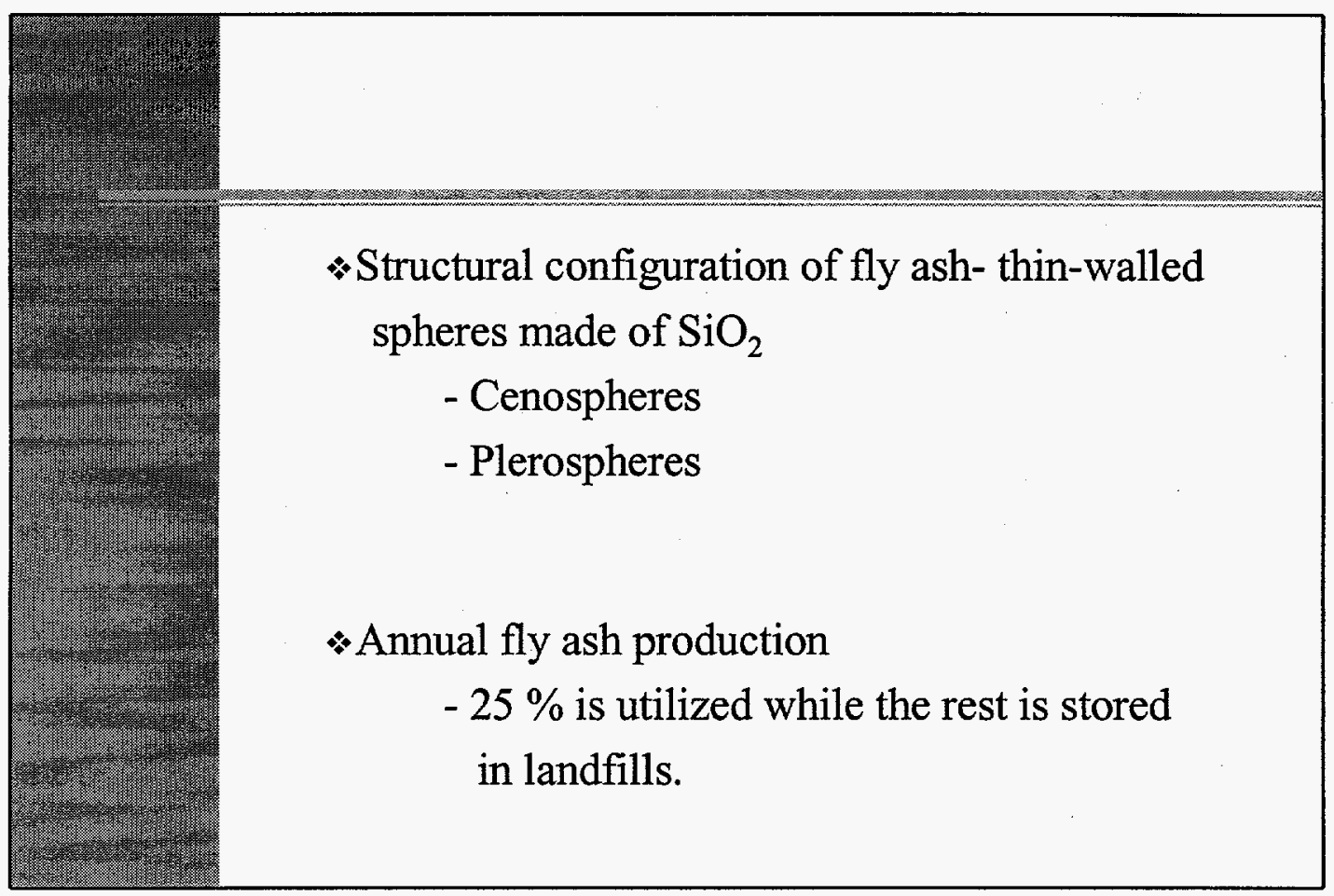




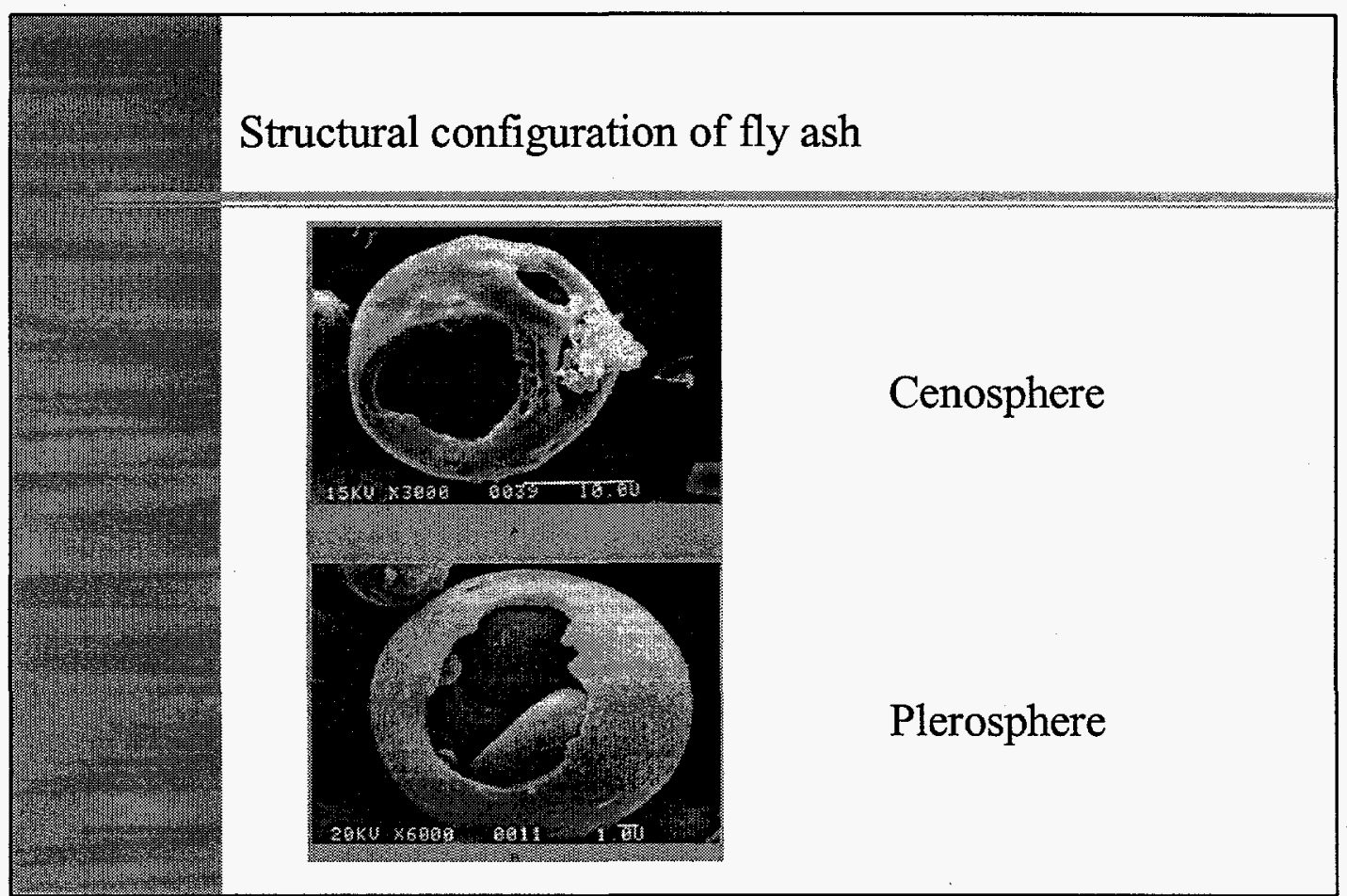




\begin{tabular}{|l|l|}
\hline & USE OF FLY ASH IN CONCRETE \\
\hline & $\begin{array}{l}\text { Replacement of Portland Cement } \\
\text { * Hydraulic cement that contains } \\
\text { various proportions of four primary } \\
\text { compounds: } \mathrm{Ca}_{3} \mathrm{SiO}_{5}, \mathrm{Ca}_{2} \mathrm{SiO}_{4}, \mathrm{Ca}_{3} \mathrm{Al}_{2} \mathrm{O}_{6} \\
\text { and } \mathrm{Ca}_{4} \mathrm{Al}_{2} \mathrm{~F}_{2} \mathrm{O}_{10} \cdot\end{array}$ \\
& \\
& $2 \mathrm{Ca}_{3} \mathrm{SiO}_{5}+6 \mathrm{H}_{2} \mathrm{O} \rightarrow \mathrm{Ca}_{3} \mathrm{Si}_{2} \mathrm{O}_{7} \cdot 3 \mathrm{H}_{2} \mathrm{O}+3 \mathrm{Ca}(\mathrm{OH})_{2}$ \\
\hline
\end{tabular}


Fly ash as a pozzolan

* Siliceous or siliceous and aluminous material that in itself possesses little or no cementitious value but will, in finely divided form and in the presence of moisture react with calcium hydroxide at ordinary temperatures to form compounds possessing cementitious properties. 


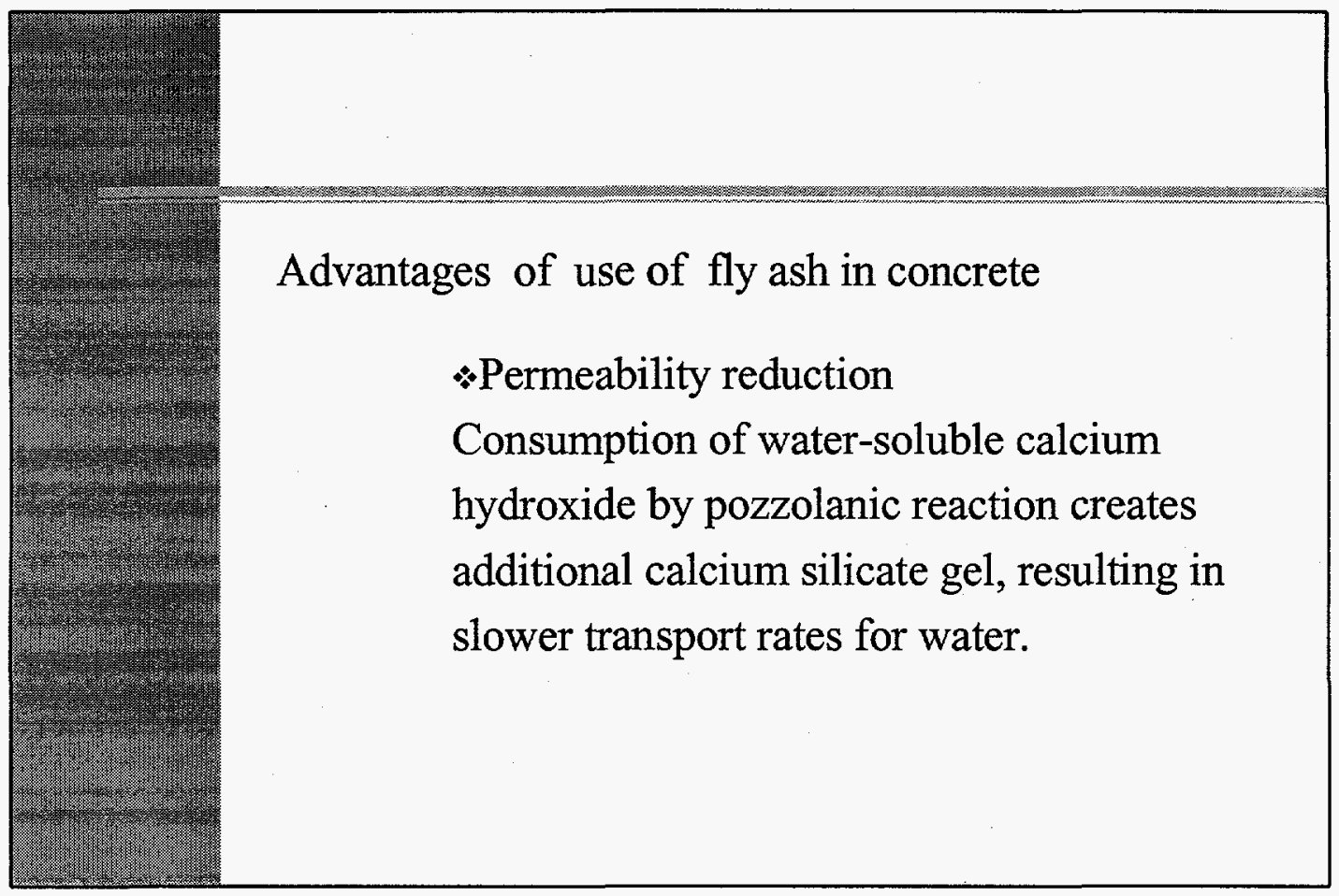




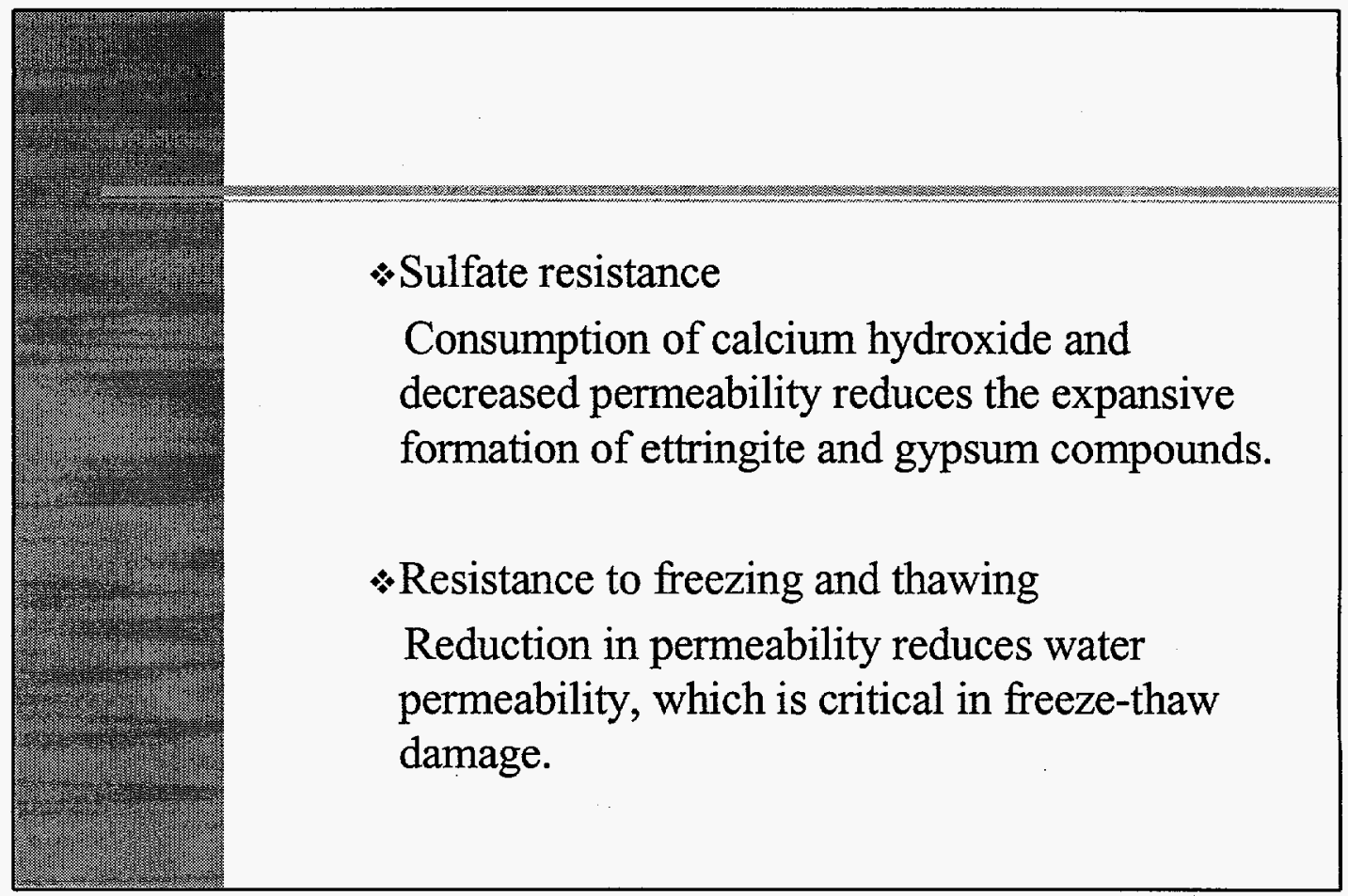




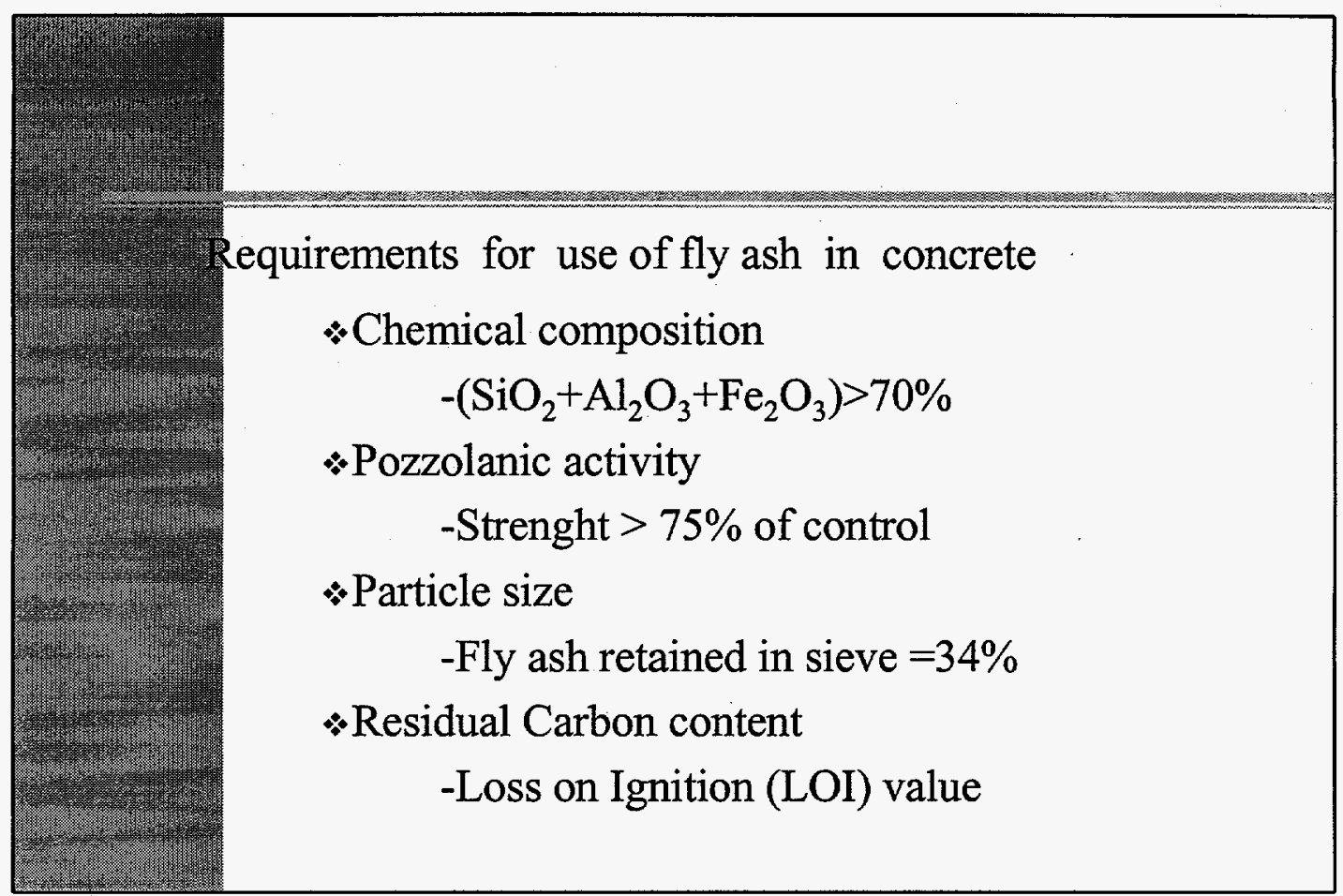




\begin{tabular}{|l|l|}
\hline & Carbon content and air entraining admixture \\
\hline & $\begin{array}{l}\text { Air -entraining admixtures-organic materials } \\
\text { that entrain a controlled quantity of air in } \\
\text { uniformly dispersed microscopic bubbles and } \\
\text { increase the ability of concrete to withstand } \\
\text { freeze-thaw cycling. } \\
\end{array}$ \\
& $\begin{array}{l}\text { Carbon in fly ash adsorbs a portion of the air- } \\
\text { entraining admixture, making it unavailable for } \\
\text { creating the needed conditions for stable air } \\
\text { bubbles. }\end{array}$ \\
\hline & \\
\hline
\end{tabular}




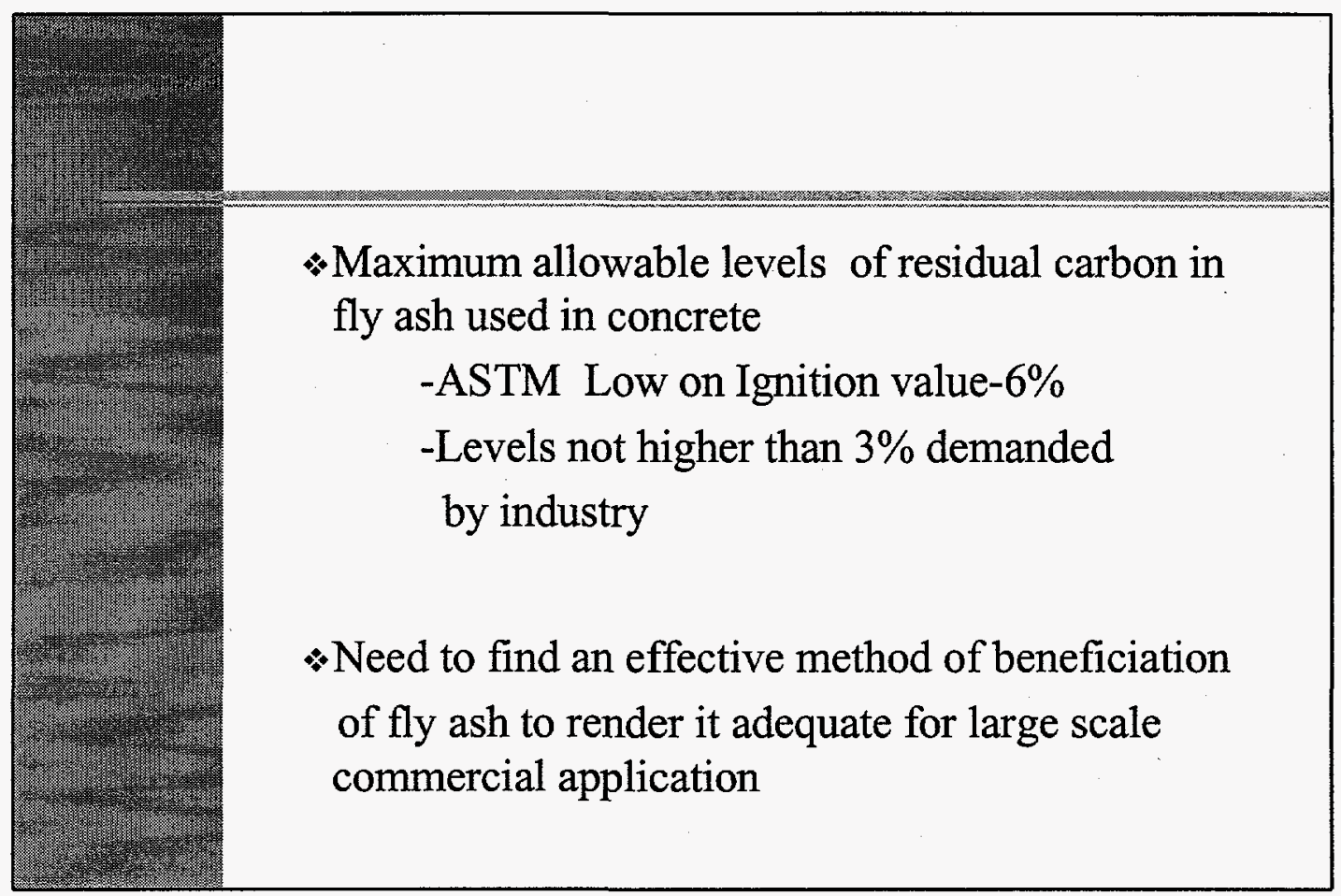


KINETICS AND MECHANISM

Processes of carbon oxidation

$*$ Mass transfer of gaseous reactants from the bulk gas phase to the carbon surface

$*$ Adsorption of reactants on the surface

* Occurrence of chemical rearrangements

$*$ Desorption of products

* Mass transport of the gaseous products away from the carbon surface 


\begin{tabular}{|c|c|}
\hline & Temperature zones for gasification processes \\
& * Zone I-Low reactions temperatures, rates chemically \\
controlled over the accessible surface & \\
& Zone II-Rates partially controlled by diffusion in \\
& pores, gaseous reactant concentration falls gradually \\
& to zero within the pore system \\
& * Zone III- Rates controlled only by diffusion of the \\
& gas to the external carbon surface.
\end{tabular}




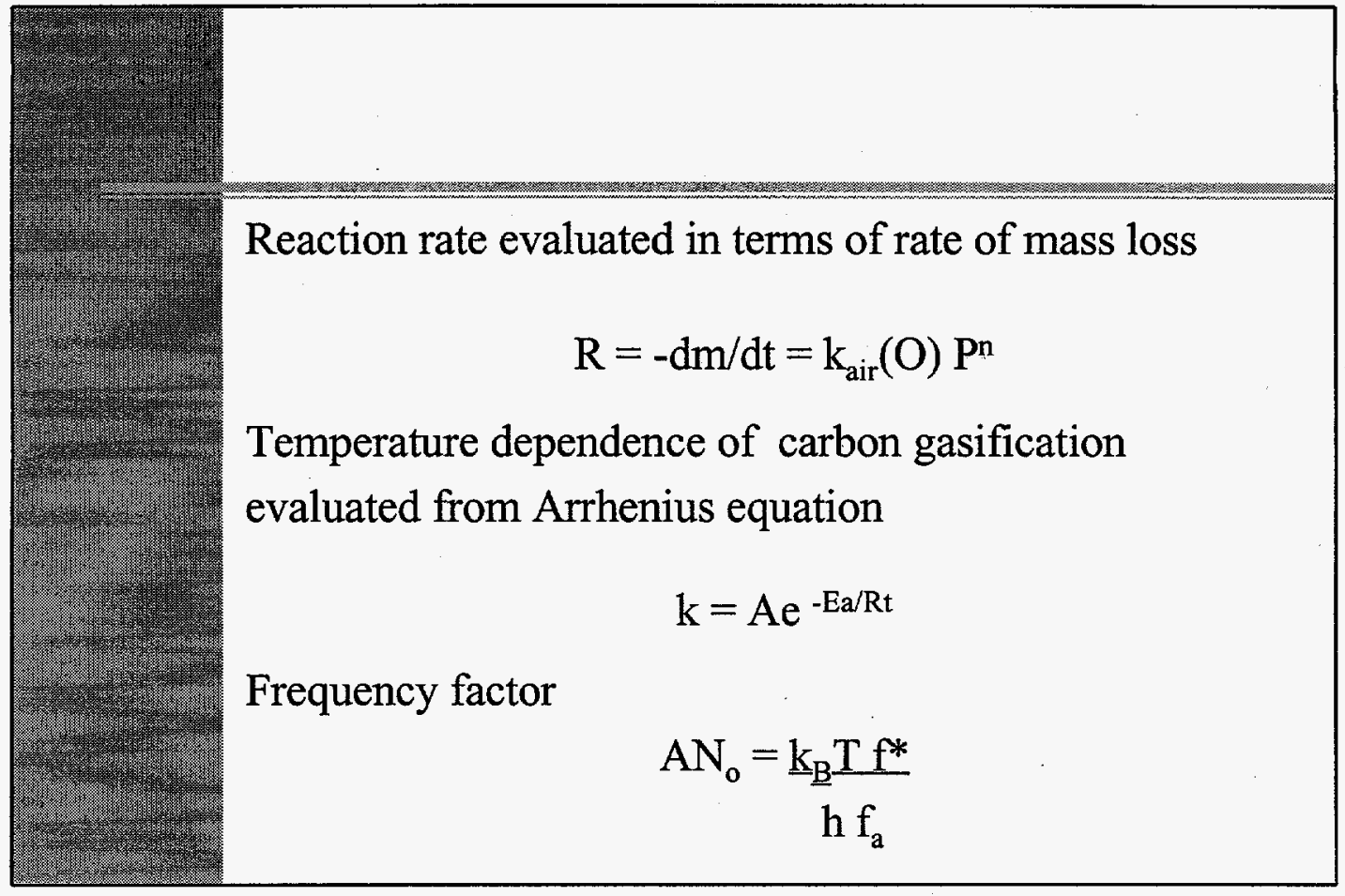




\begin{tabular}{|l|l|}
\hline & Application of Proportionality Law of Processes \\
$*$ Reaction rates calculated from linear portion \\
of sigmoid curves are not representative of the \\
physical events of the reactions. \\
* Proportionality Law of Processes: for certain \\
natural phenomena, the change of variable Y with \\
respect to change of variable X (dY/dX) is \\
proportional to the difference between a reference \\
value Yi (asymptote) and of $\mathrm{Y}$ at a given X and \\
inversely proportional to X
\end{tabular}




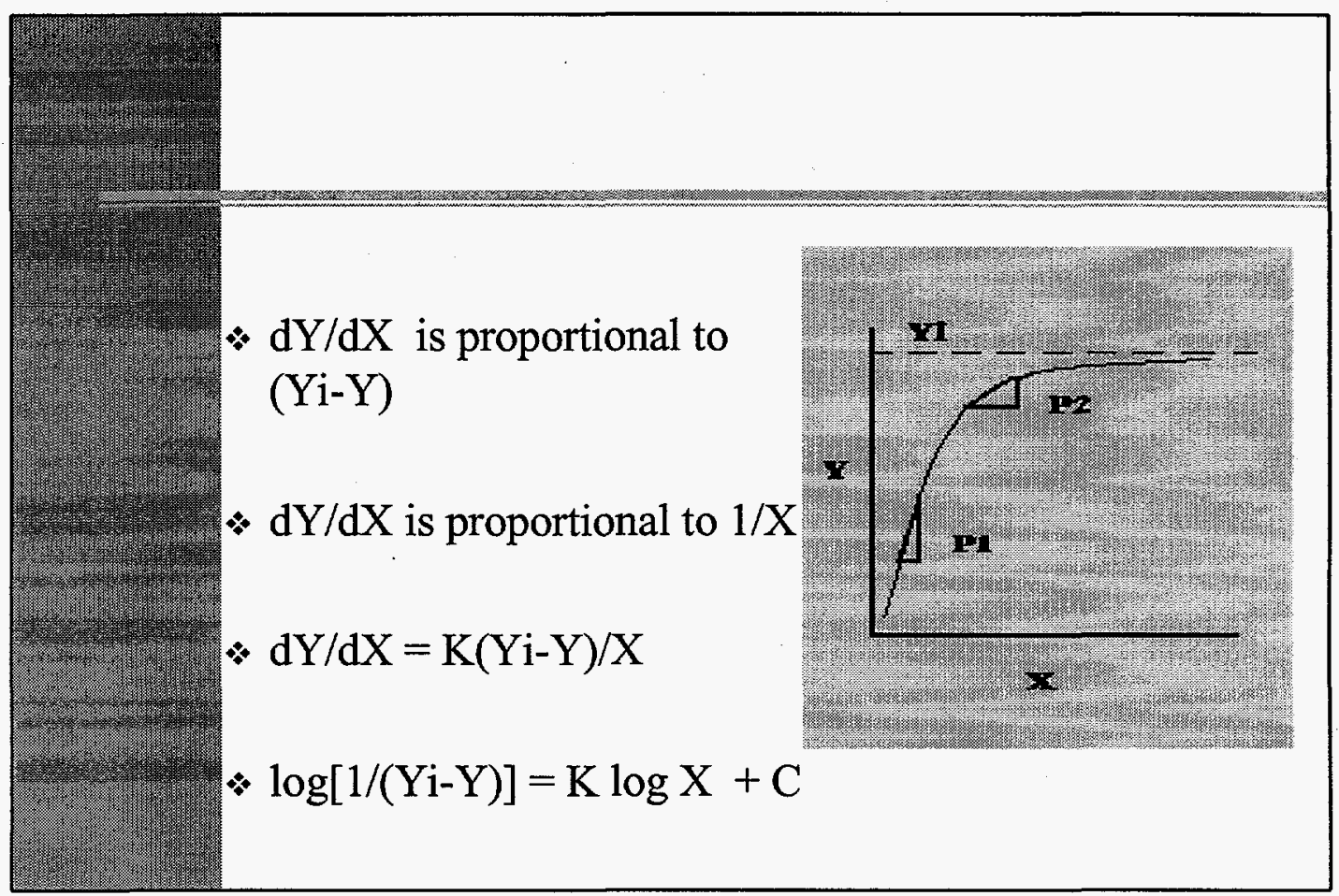




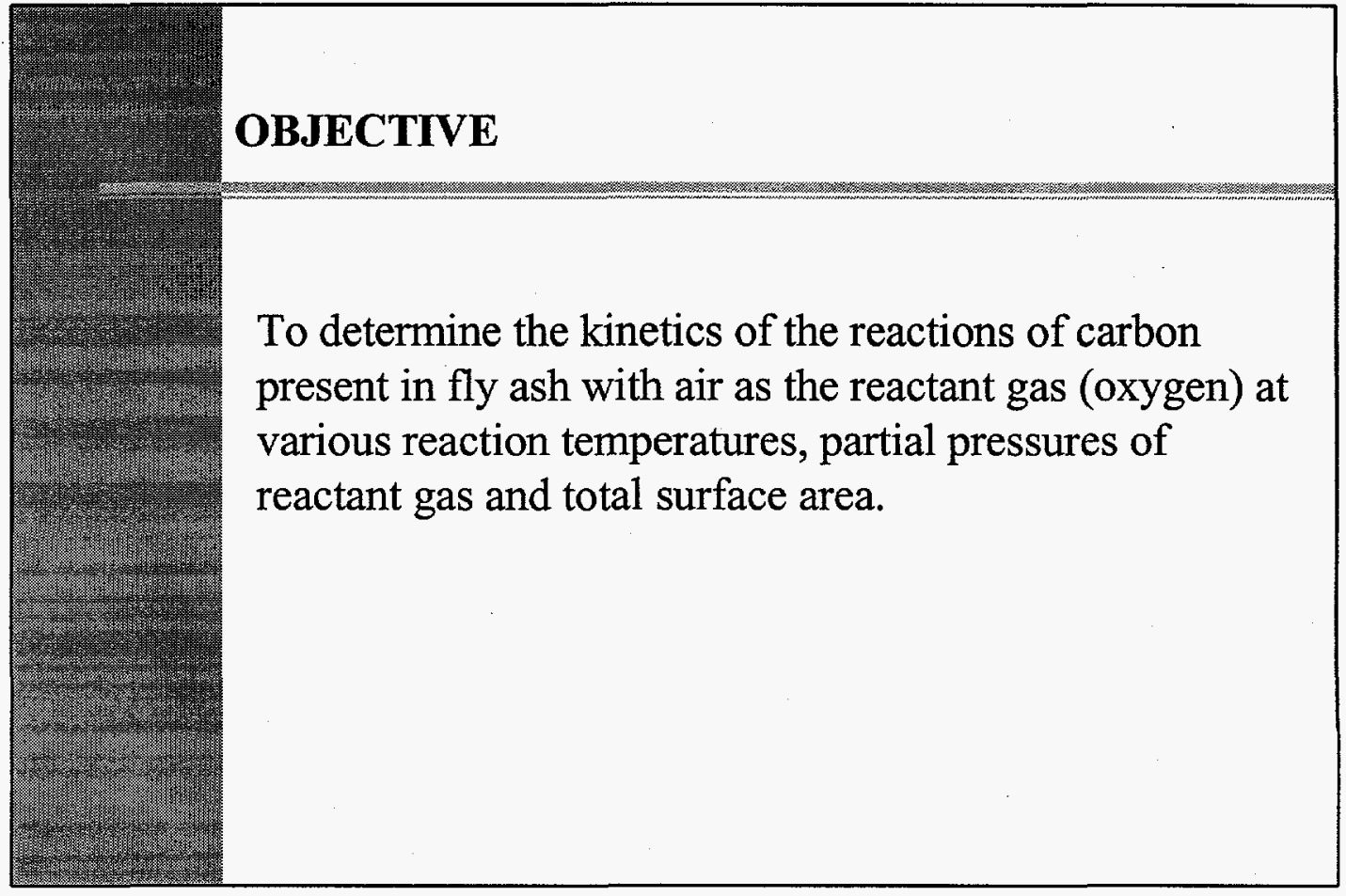




\section{EXPERIMENTAL PROCEDURES}

FLY ASH SAMPLES

* Collected from landfill-Delmarva Power Indian River Plant

* Size-fractioned using sieves with openings of 44, 74,149 , and 250 micrometers

* Dried at $200^{\circ} \mathrm{C}$ under nitrogen for 3 hours using a Lindberg furnance 


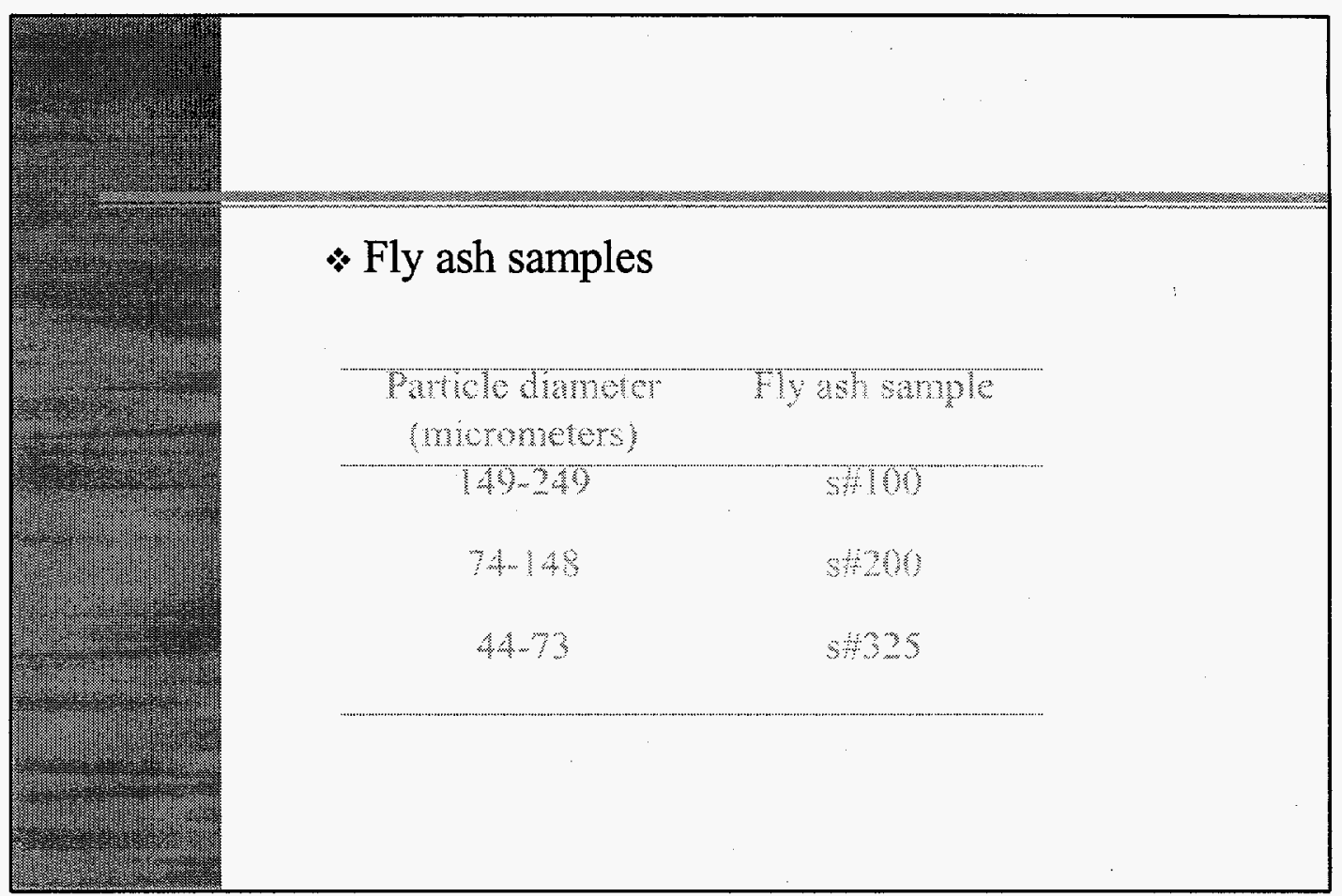




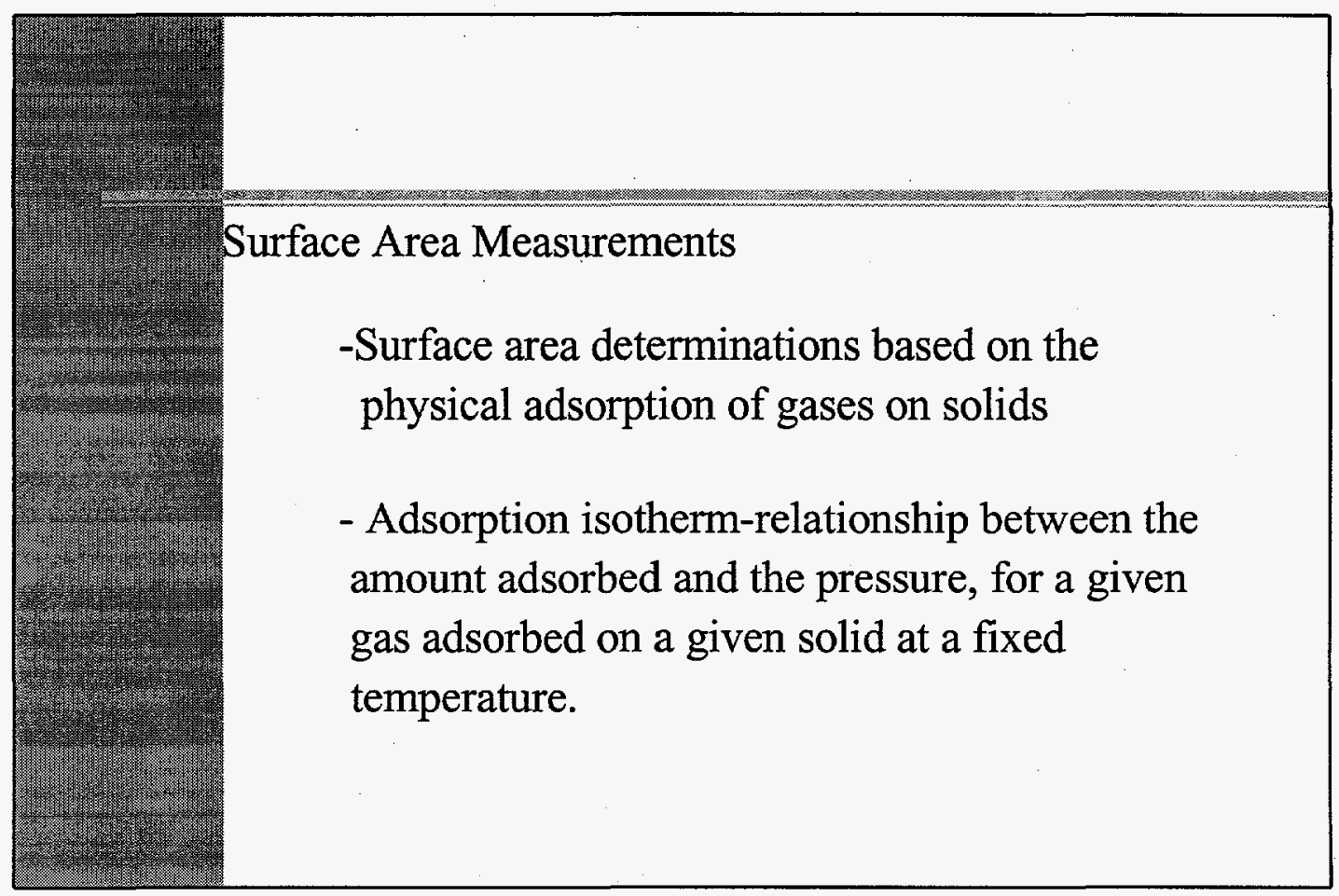




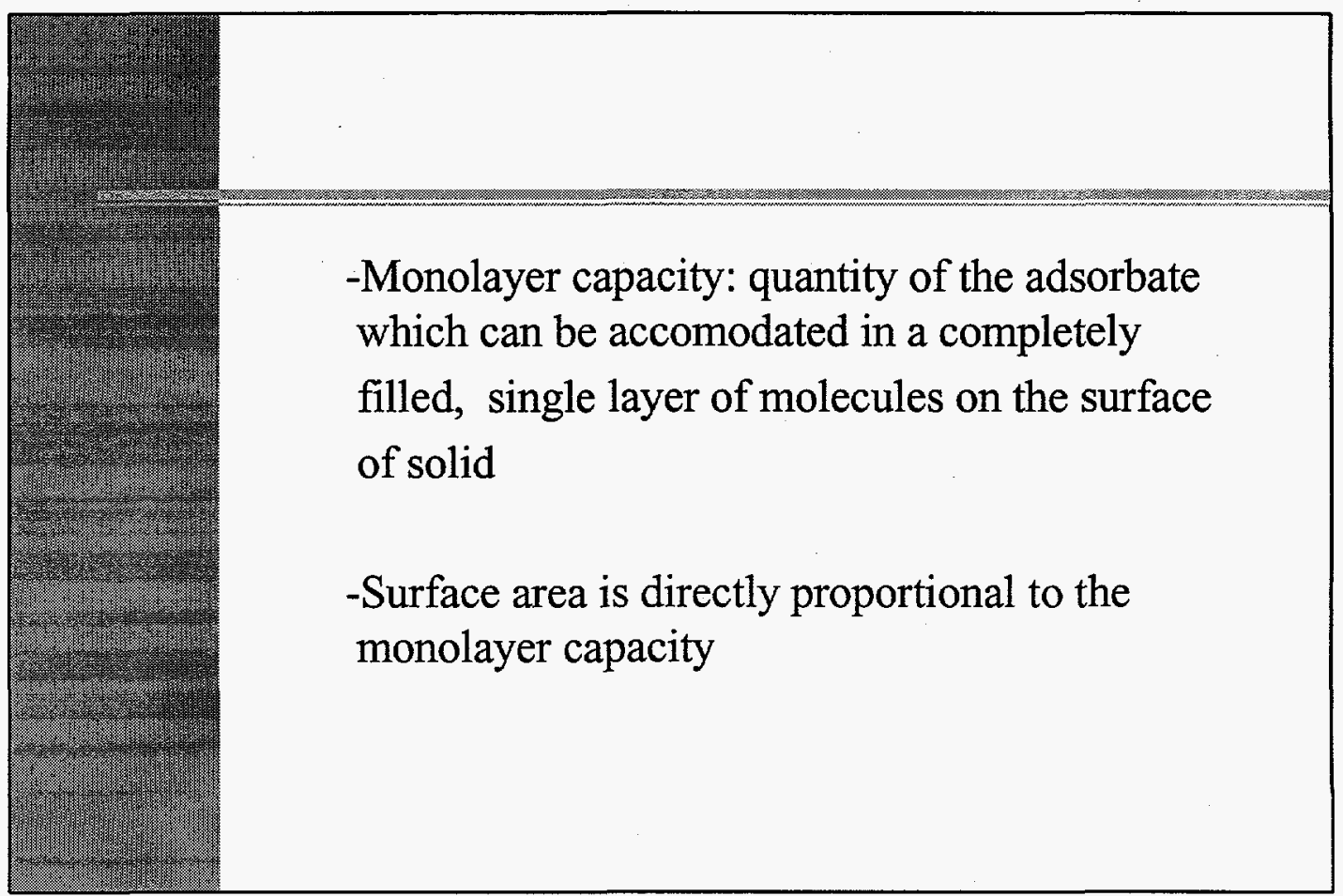




\begin{tabular}{|l|l|}
\hline & Brunauer-Emmett-Teller (BET) Theory \\
& $\begin{array}{l}\text { Describes multilayer adsorption of gases on a wide } \\
\text { range of porous and non-porous solids. }\end{array}$ \\
& $\frac{1}{\mathrm{~V}\left[\left(\mathrm{P}_{\mathrm{o}} / \mathrm{P}\right)-1\right]}=\frac{1}{\left(\mathrm{~V}_{\mathrm{m}} \mathrm{c}^{1}\right)}+\frac{\left(\mathrm{c}^{1}-1\right) \mathrm{P}}{\mathrm{V}_{\mathrm{m}} \mathrm{c}^{1} \mathrm{P}_{\mathrm{o}}}$ \\
& $\begin{array}{l}\text { where } \mathrm{V} \text { is the volume adsorbed, } \mathrm{V}_{\mathrm{m}} \text { is the } \\
\text { monolayer capacity, } \mathrm{P} \text { is the pressure of the } \\
\text { adsorbate, } \mathrm{P}_{\mathrm{o}} \text { is the normal vapor pressure of } \\
\text { the gas, and } \mathrm{c}^{1} \text { is a constant }\end{array}$ \\
\hline
\end{tabular}




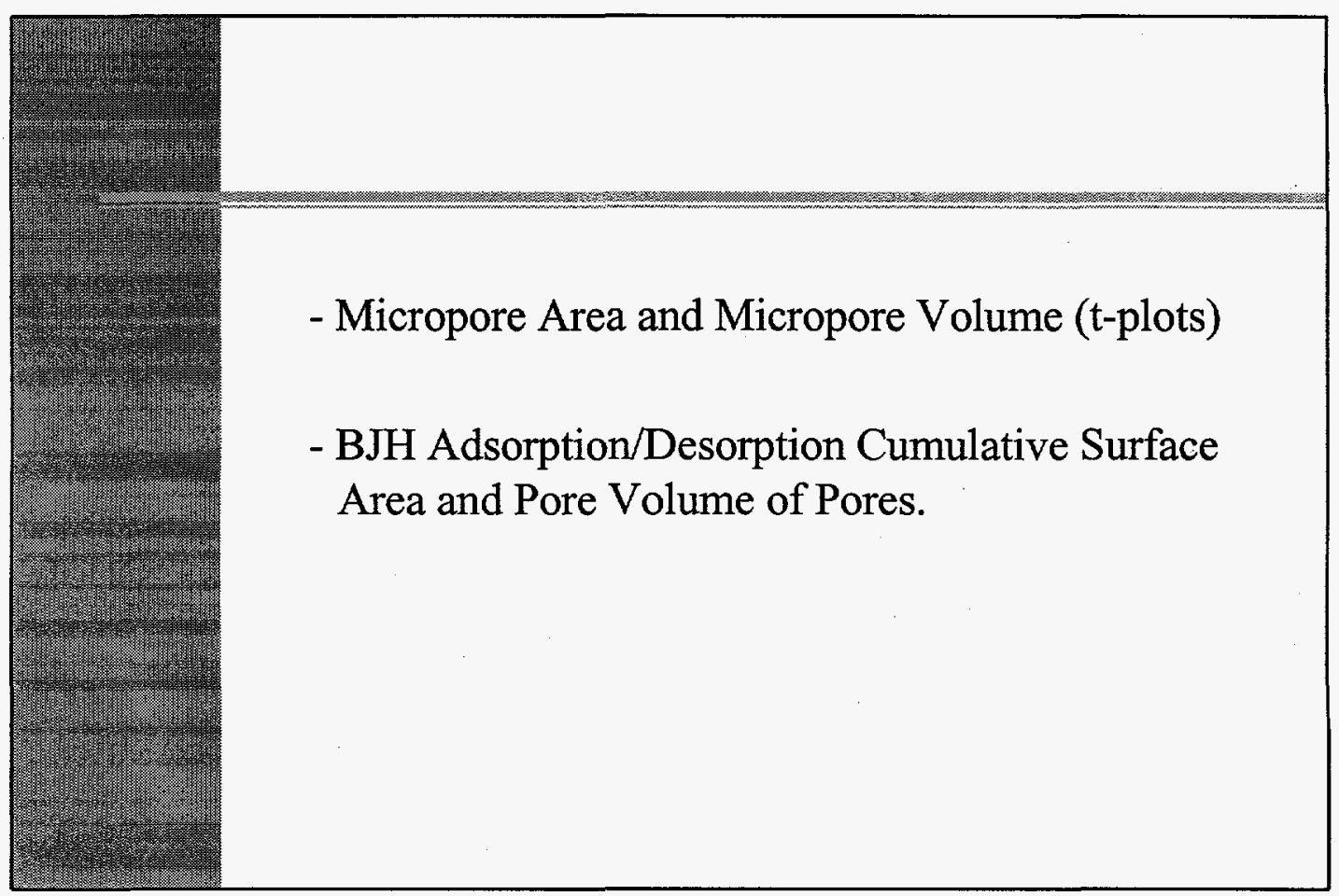




\begin{tabular}{|l|ll|}
\hline & & \\
\hline & & \\
\hline & Surface Area and Porosimetry System-ASAP 2000 \\
& Analysis Adsorptive & Nitrogen \\
& $\begin{array}{l}\text { Temperature } \\
\text { Molecular cross-sectional } \\
\end{array}$ & $77.35 \mathrm{~K}$ \\
& $\begin{array}{l}\text { area } \\
\text { Non-ideality factor }\end{array}$ & $0.162 \mathrm{~nm}^{2}$ \\
& Equilibration interval & 0.000066 \\
& & $5 \mathrm{secs}$ \\
& & \\
\hline
\end{tabular}




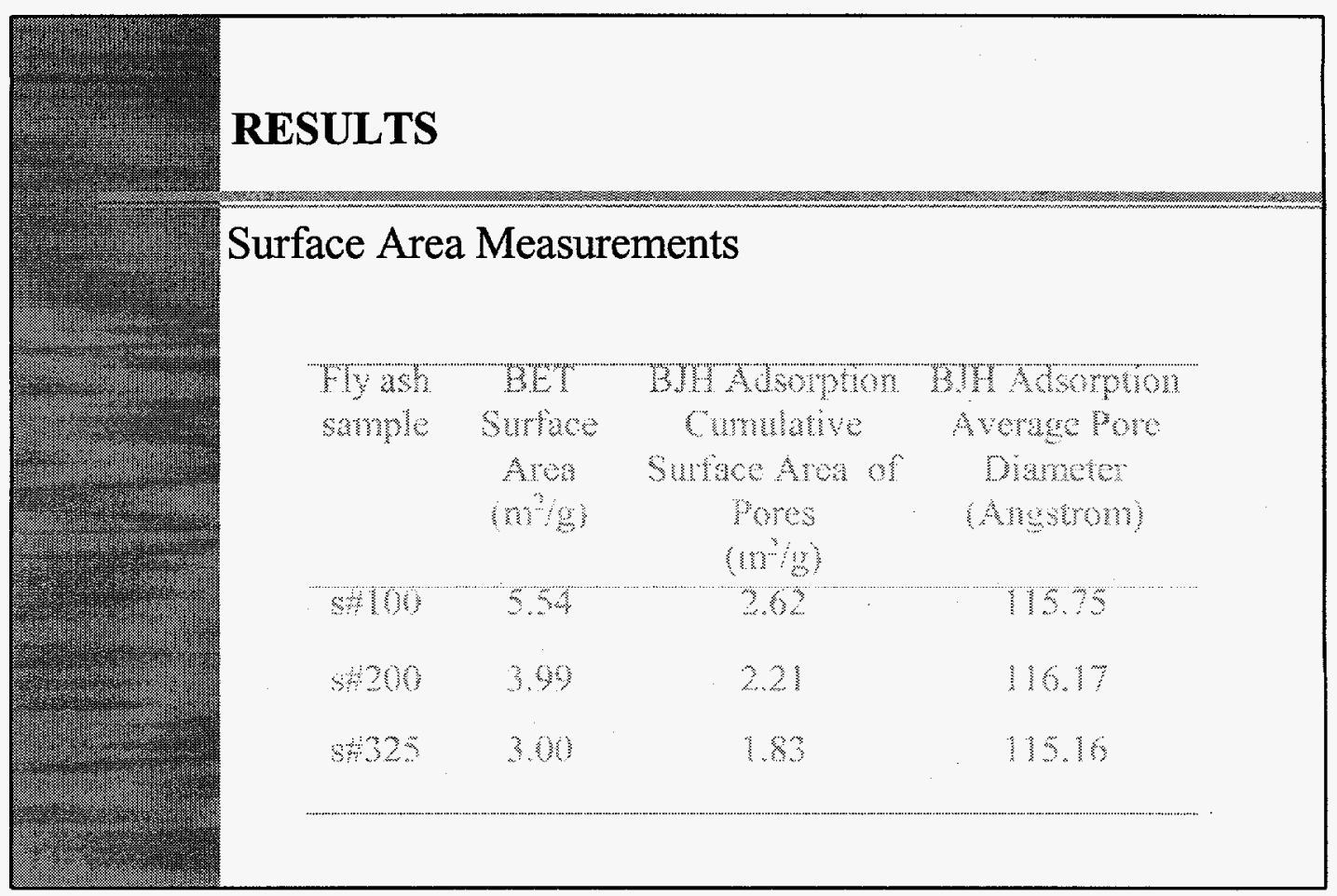




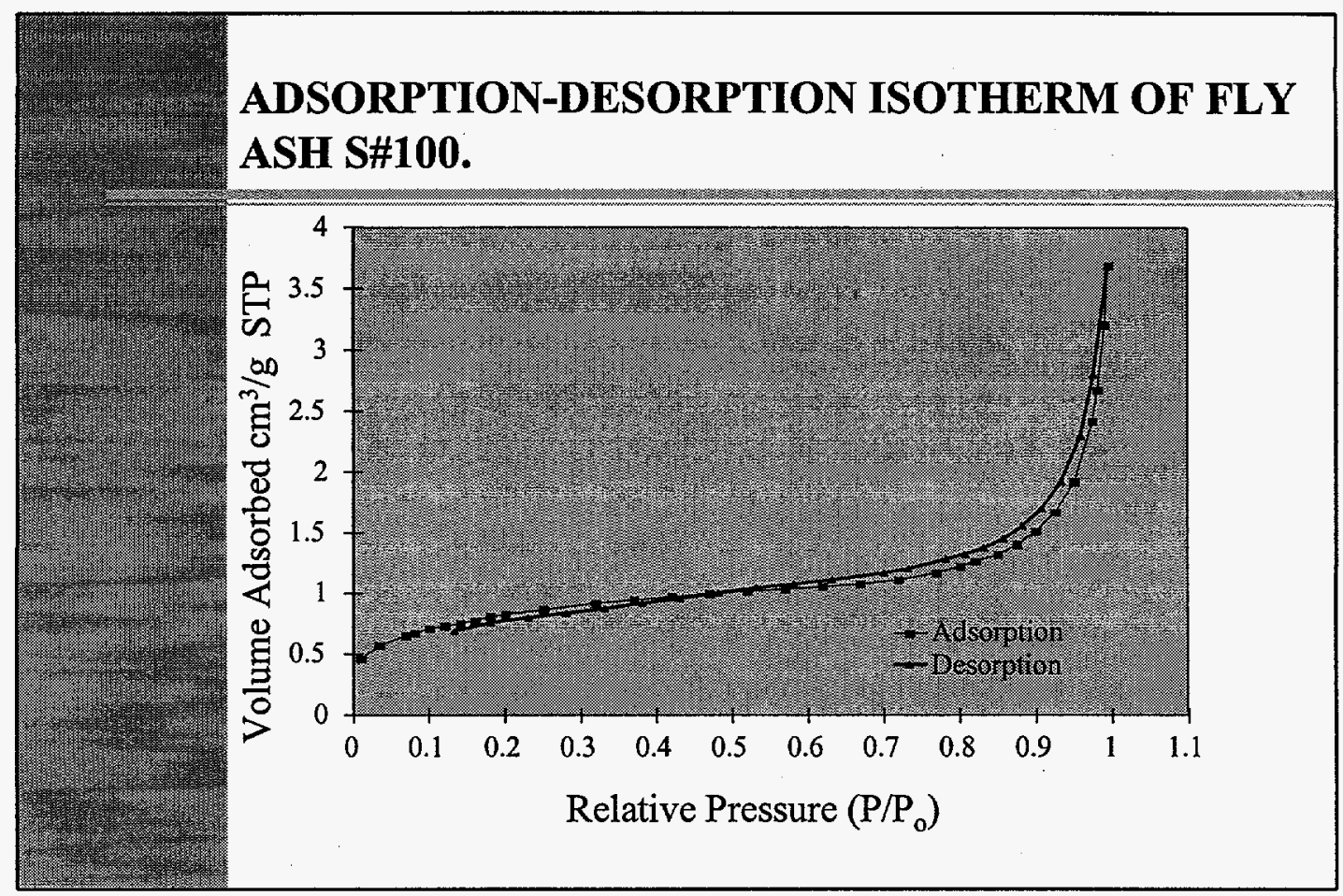




\section{t-PLOT FOR FLY ASH S\#100}

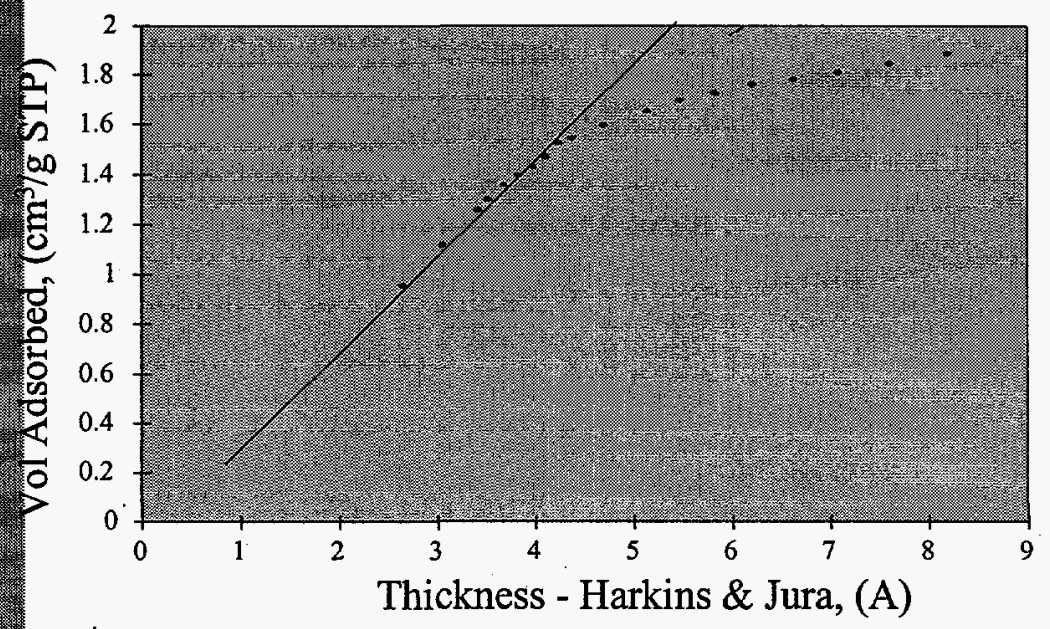




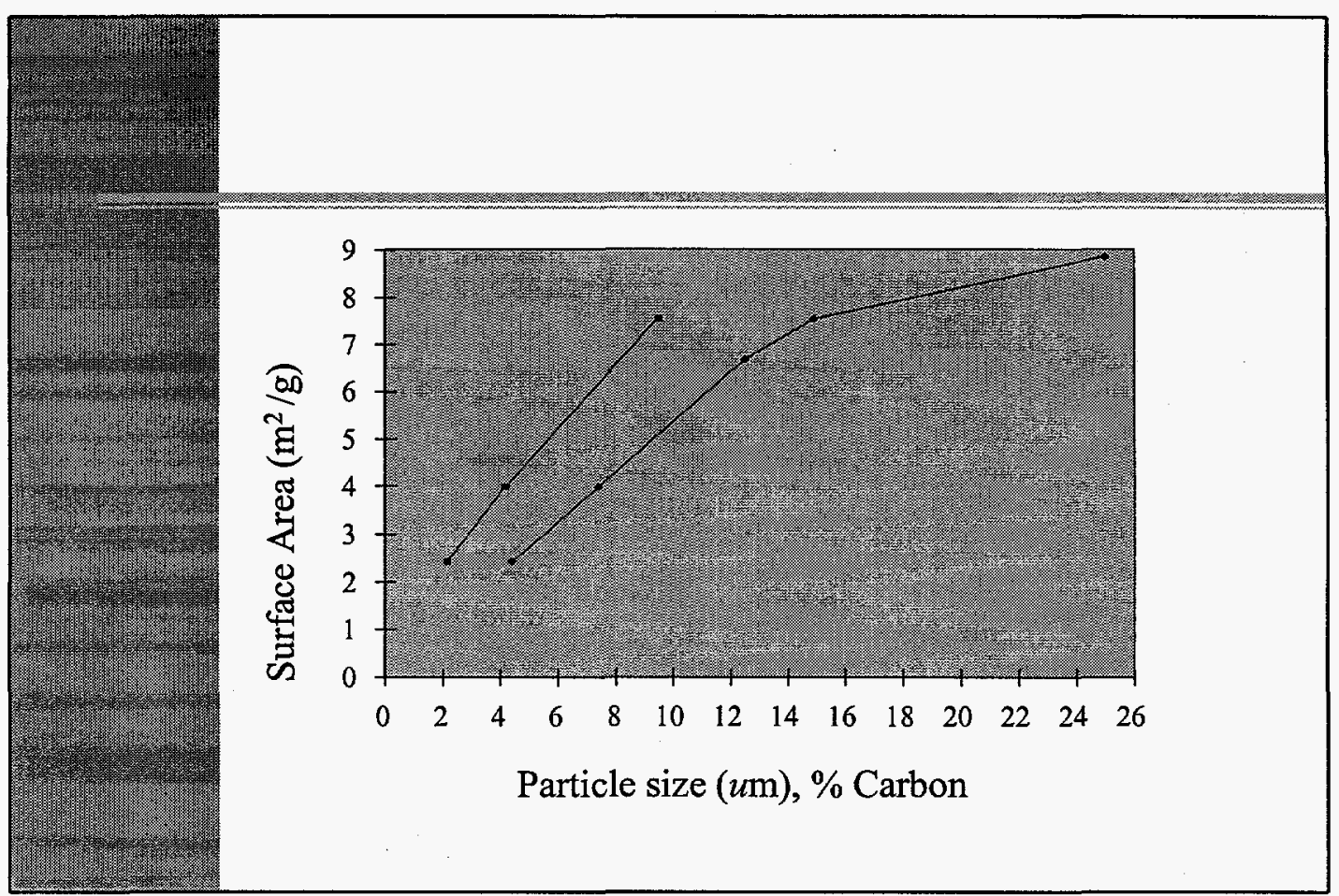




\begin{tabular}{|c|c|}
\hline & \\
\hline & $\begin{array}{c}\text { Results from surface area measurements } \\
\text { - Surface area increases as particle size } \\
\text { increases. } \\
\text { - Adsorption-desorption isotherms show } \\
\text { hysteresis loops, indicating porosity } \\
\end{array}$ \\
& $\begin{array}{l}\text { - t-plots confirm porosity of fly ash } \\
\text { - Average pore diameters for fly ash samples } \\
\text { are similar }\end{array}$ \\
\hline
\end{tabular}




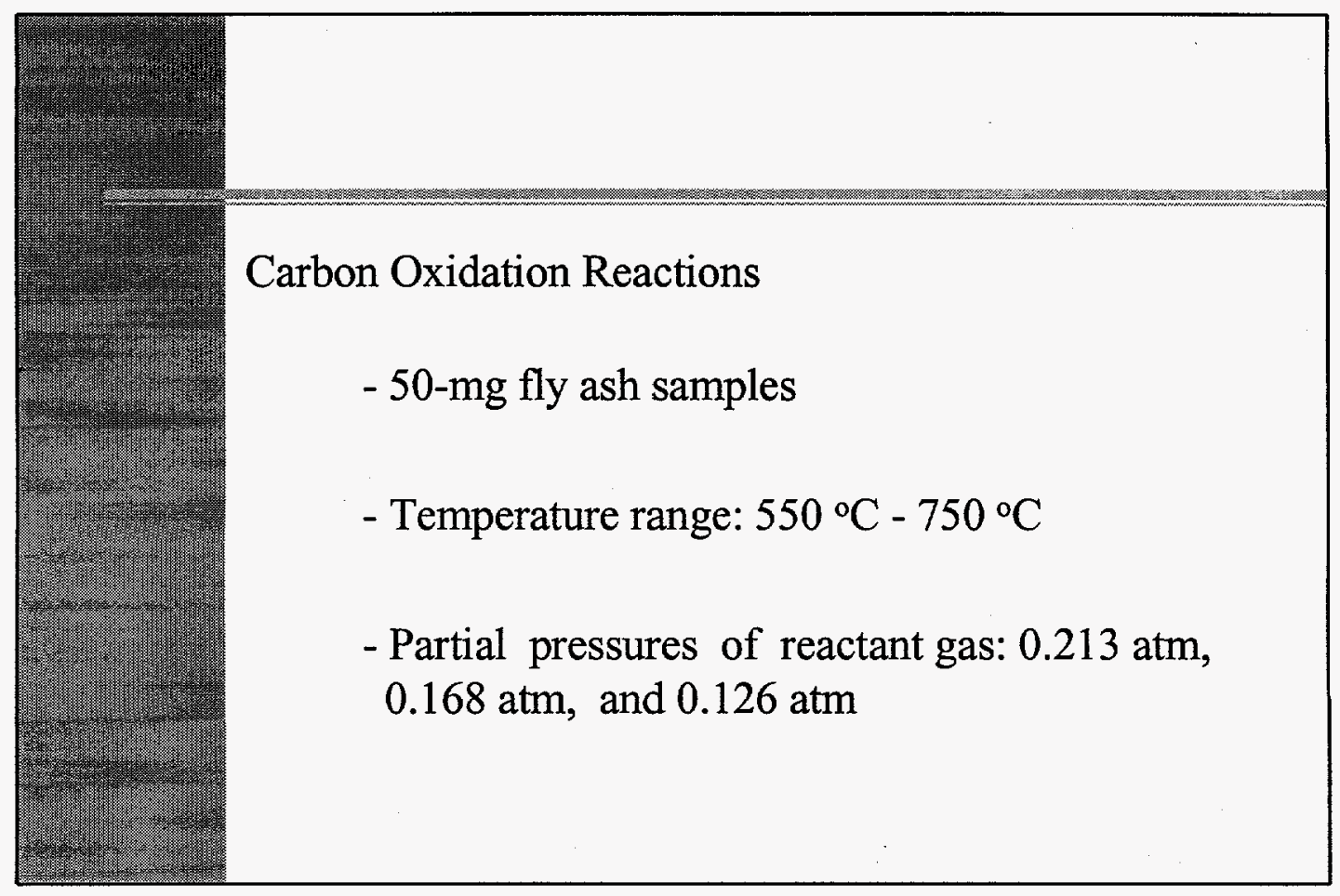




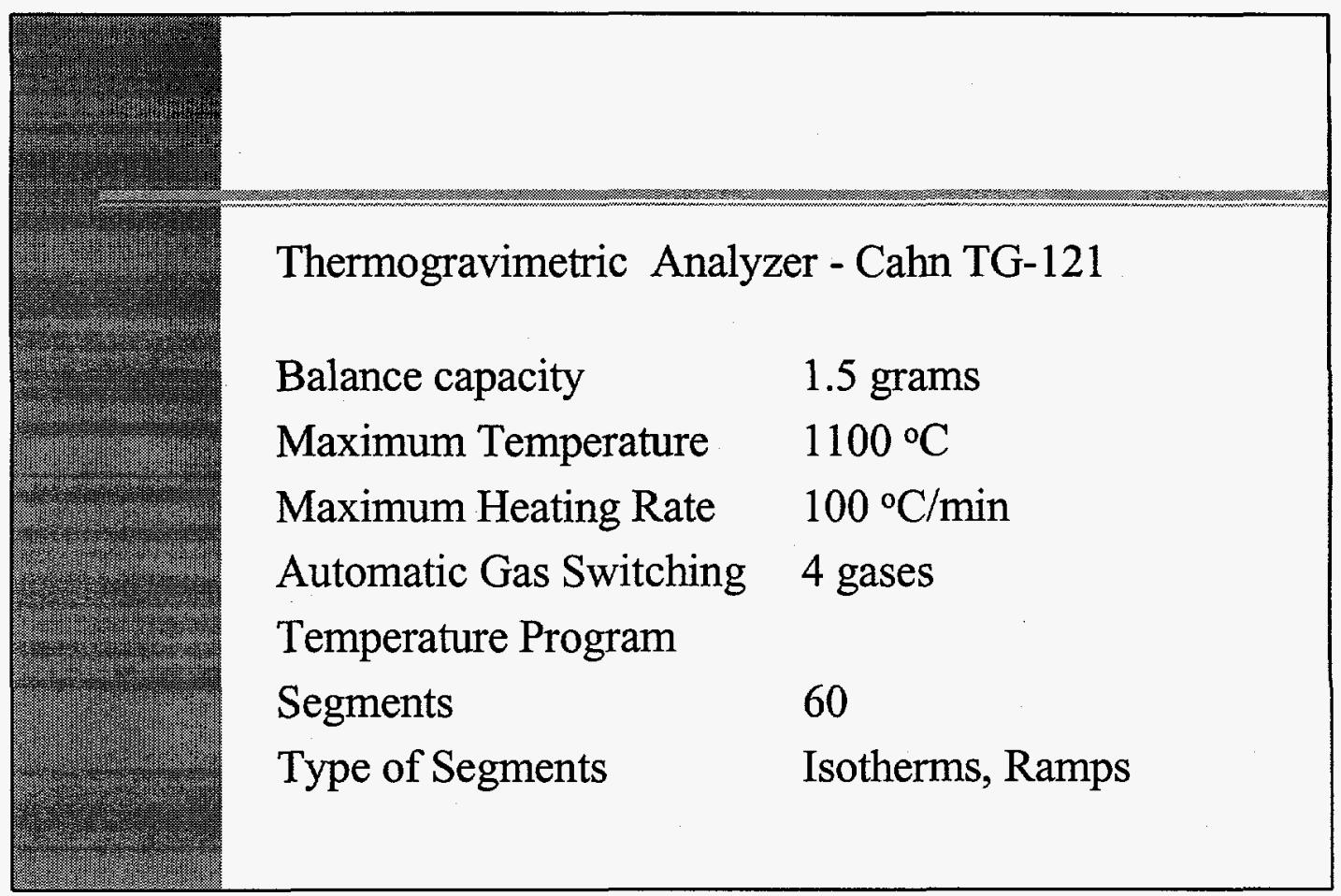




\section{TEMPERATURE VS. TIME PROFILE}

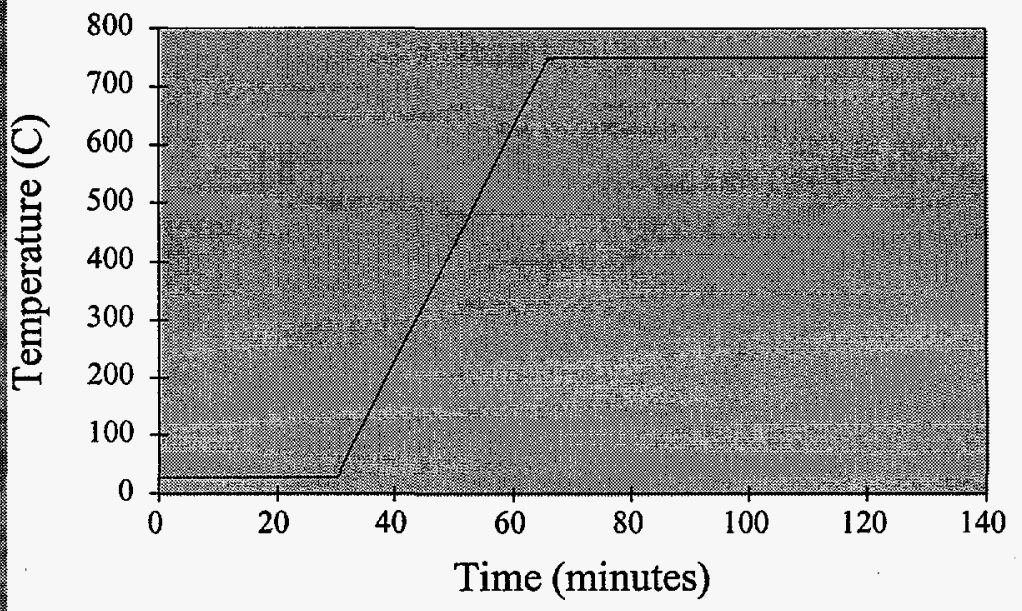




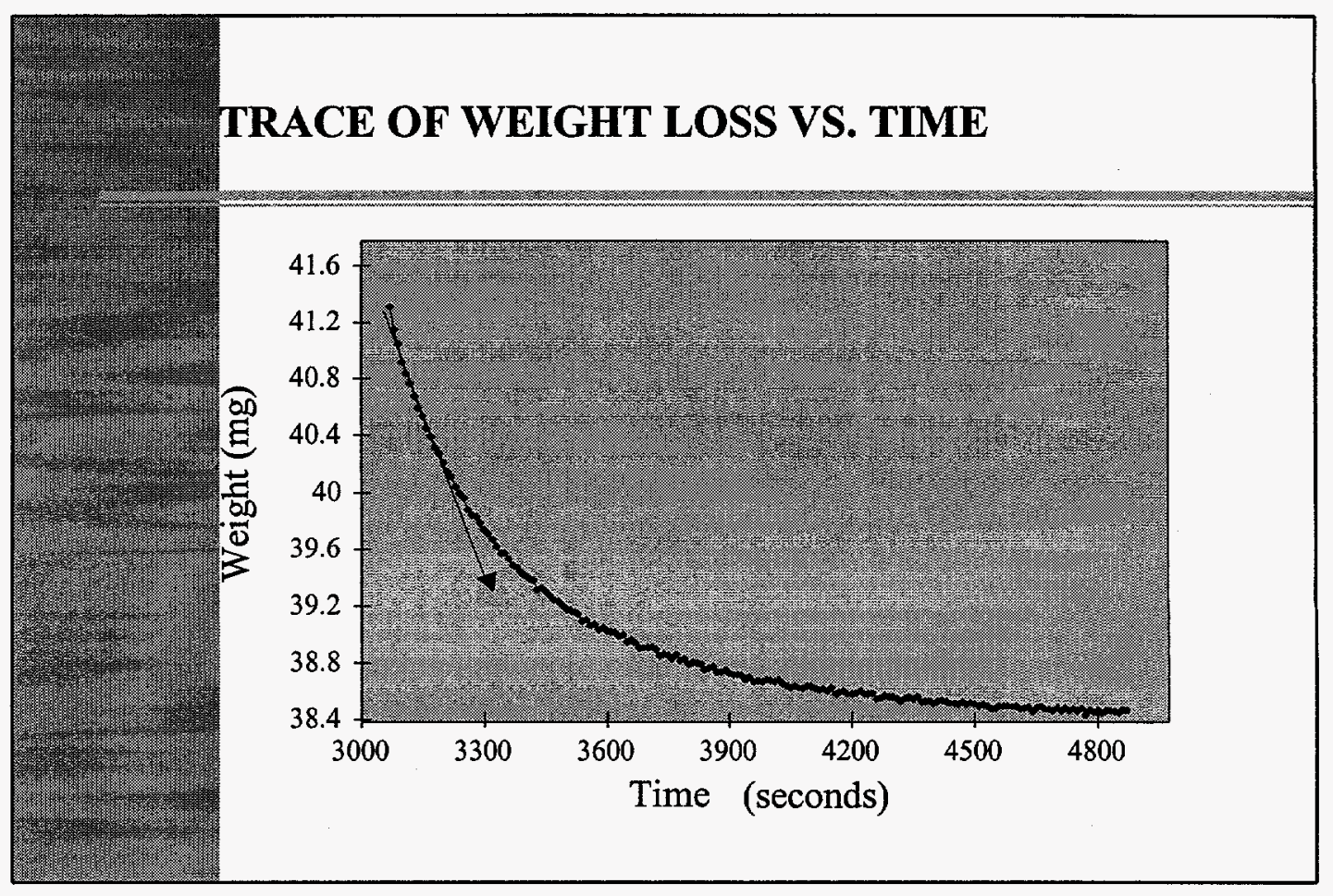

\section{PARA QUE SE VEA BIEN LA LETRA DEBE SER AL MENOS 18}




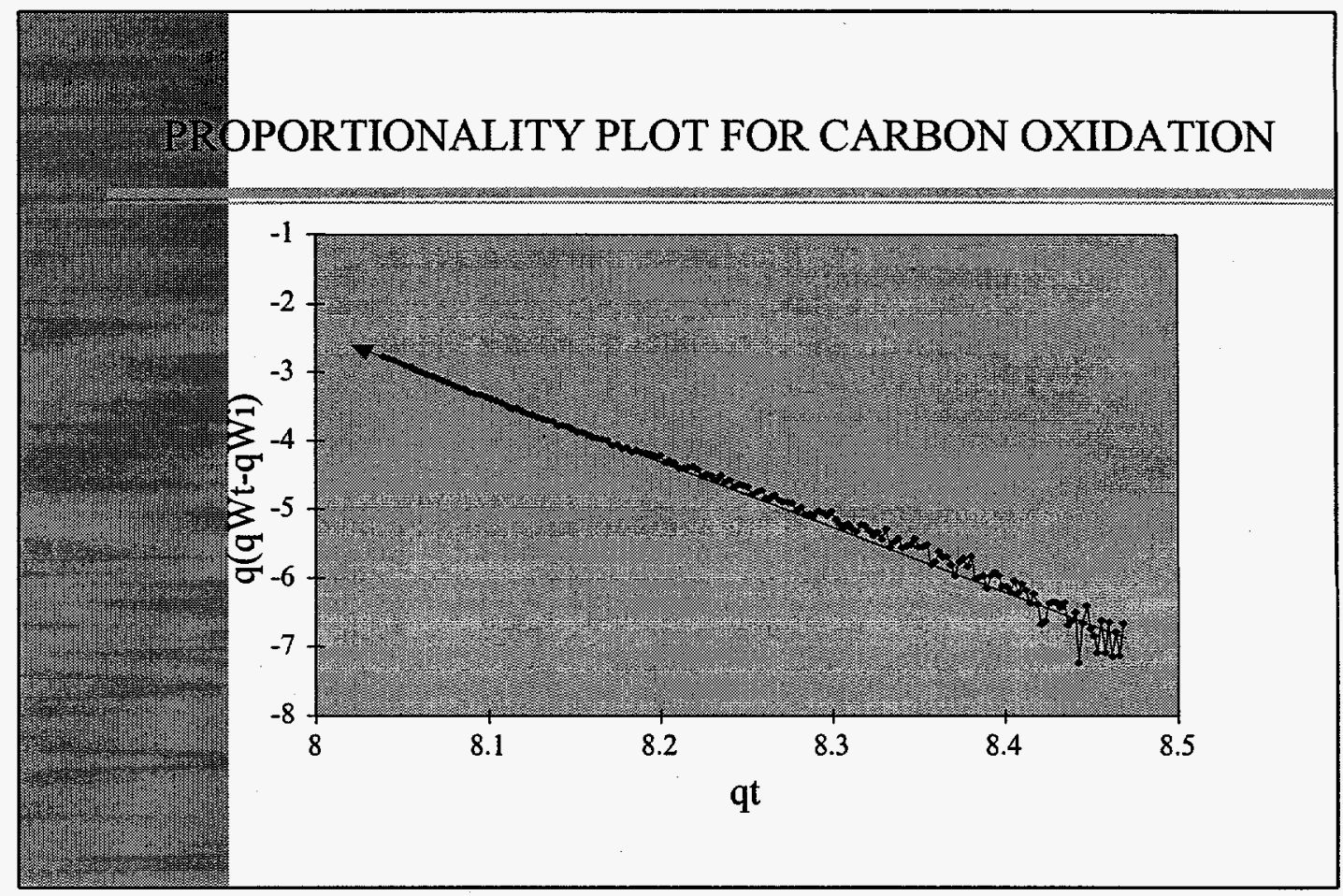




\section{RESULTS}

Reaction rates for carbon oxidation at $0.213 \mathrm{~atm}$

(Rates are in $\mathrm{mg} / \mathrm{g} \cdot \mathrm{m}^{2} \mathrm{sec}$ )

$\begin{array}{cccc}\text { Temperature } & \text { SHb0 } & \$ 400 & \text { s.325 } \\ \text { o } & & & \\ 550 & 0.0188 & 0.0060 & 0.0035 \\ 650 & 0.0736 & 0.0219 & 0.0290 \\ 750 & 0.1520 & 0.1586 & 0.1462\end{array}$




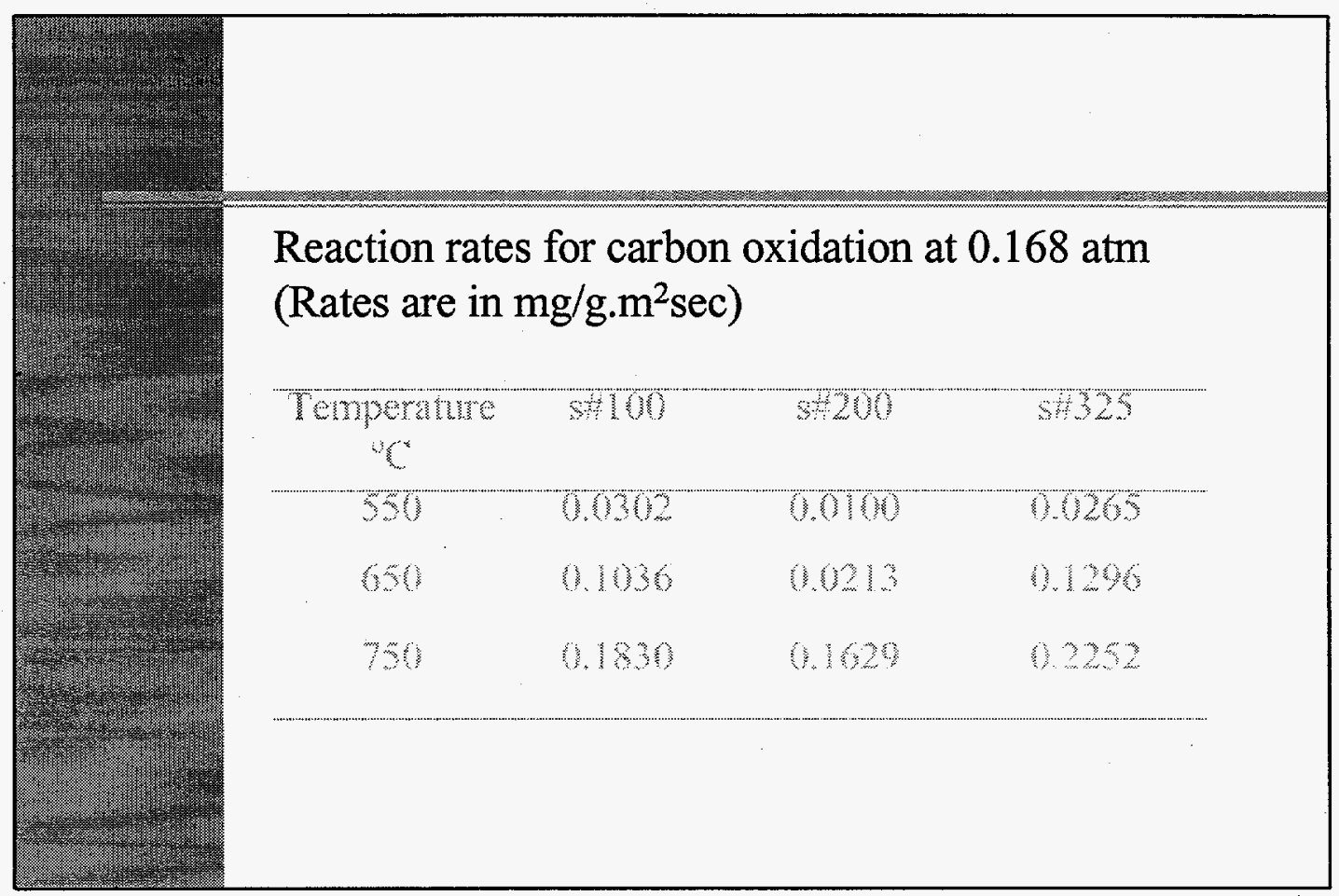


Reaction rates for carbon oxidation at $0.126 \mathrm{~atm}$ (Rates are in $\mathrm{mg} / \mathrm{g} \cdot \mathrm{m}^{2} \mathrm{sec}$ )

\begin{tabular}{|c|c|c|c|}
\hline $\begin{array}{c}\text { Temperature } \\
{ }^{\circ} \mathrm{C}\end{array}$ & shloo & $5 \$ 200$ & $\$ 325$ \\
\hline 550 & 0.3345 & 0.0147 & 0,0675 \\
\hline 650 & 0.1710 & 0.1100 & 02110 \\
\hline 750 & 0.2320 & 0.1724 & 0.2455 \\
\hline
\end{tabular}




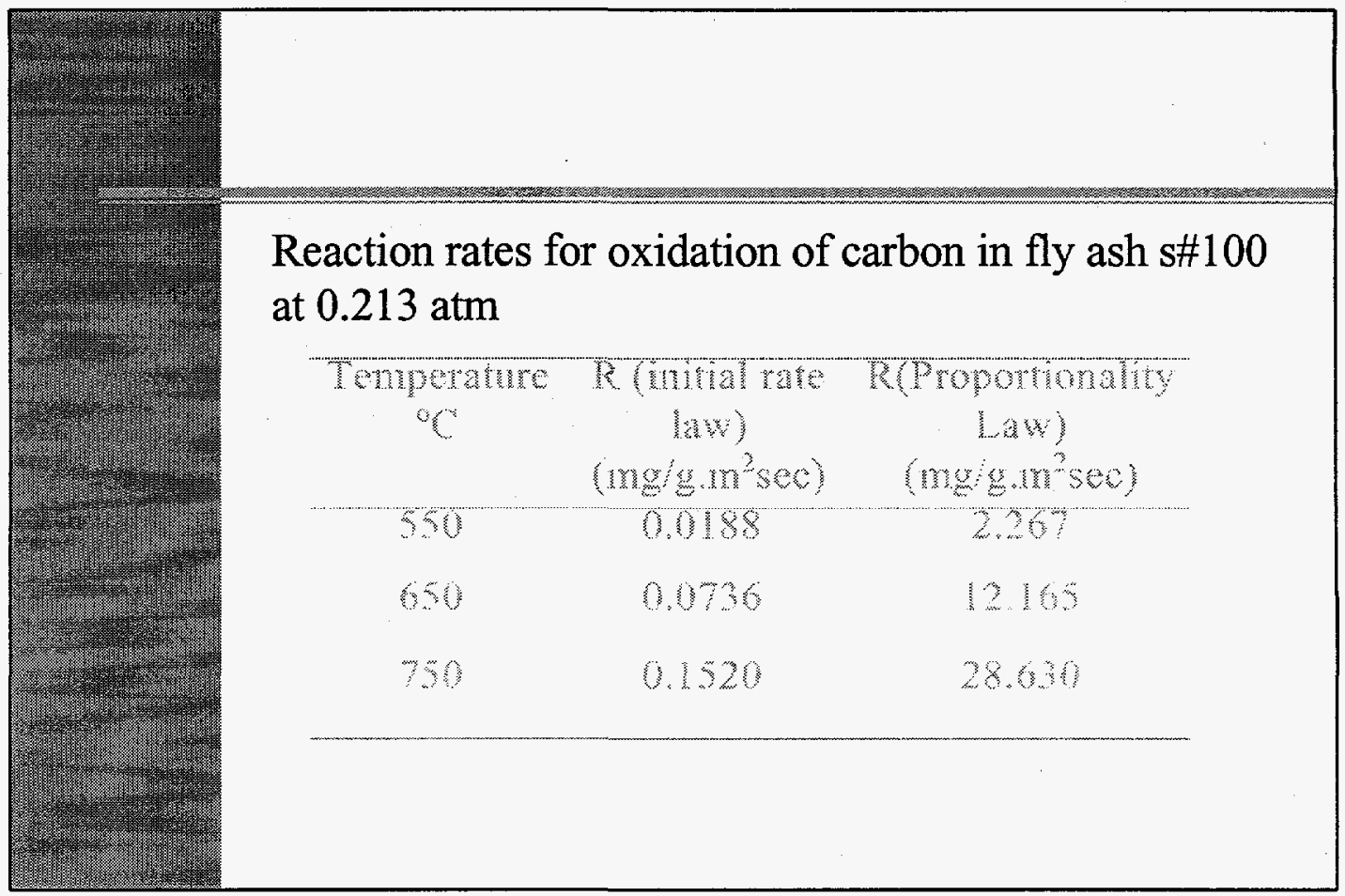




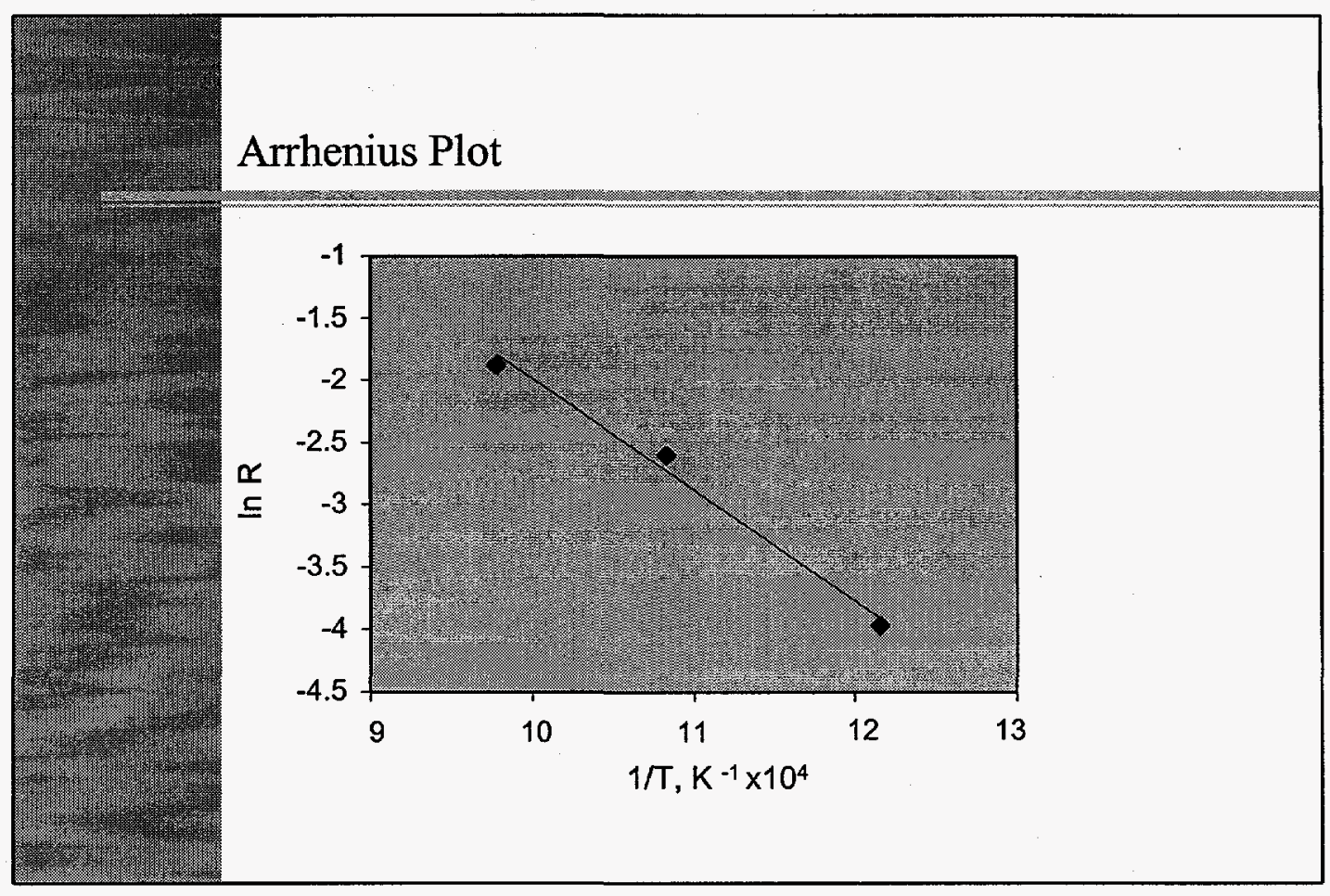


Arrhenius parameters for fly ash samples

\begin{tabular}{|c|c|c|c|}
\hline $\begin{array}{c}\mathrm{Po}_{2} \\
(\mathrm{~atm})\end{array}$ & 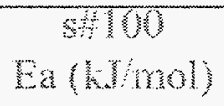 & 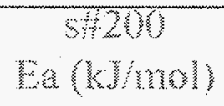 & $\begin{array}{c}\$ \% 33 \\
\text { m(k)mol) }\end{array}$ \\
\hline 0.213 & 3.85 & 108.463 & 131.44 \\
\hline 0.168 & 68.28 & 95.78 & 7612 \\
\hline 0136 & 63.81 & 88.07 & 4392 \\
\hline
\end{tabular}




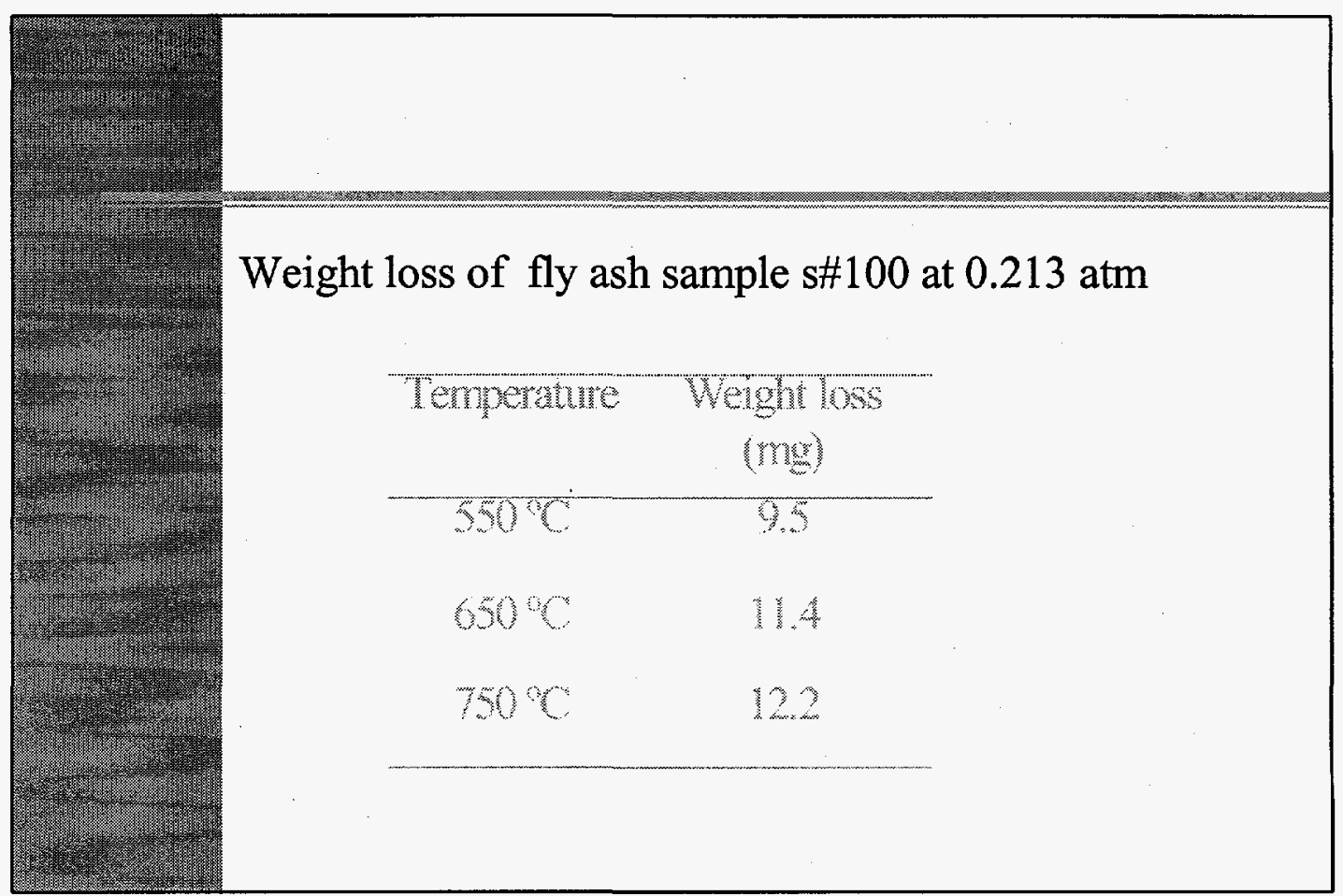




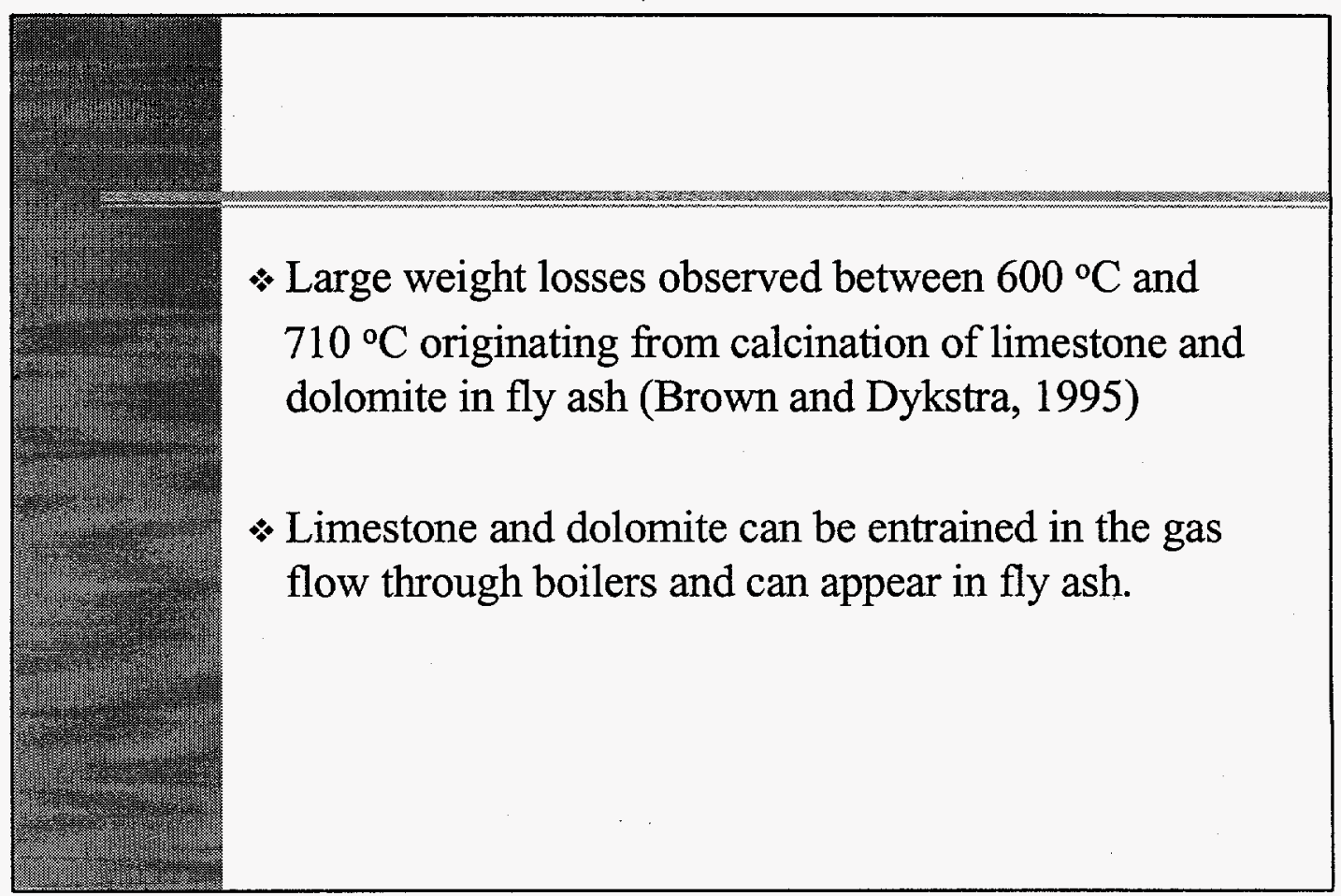




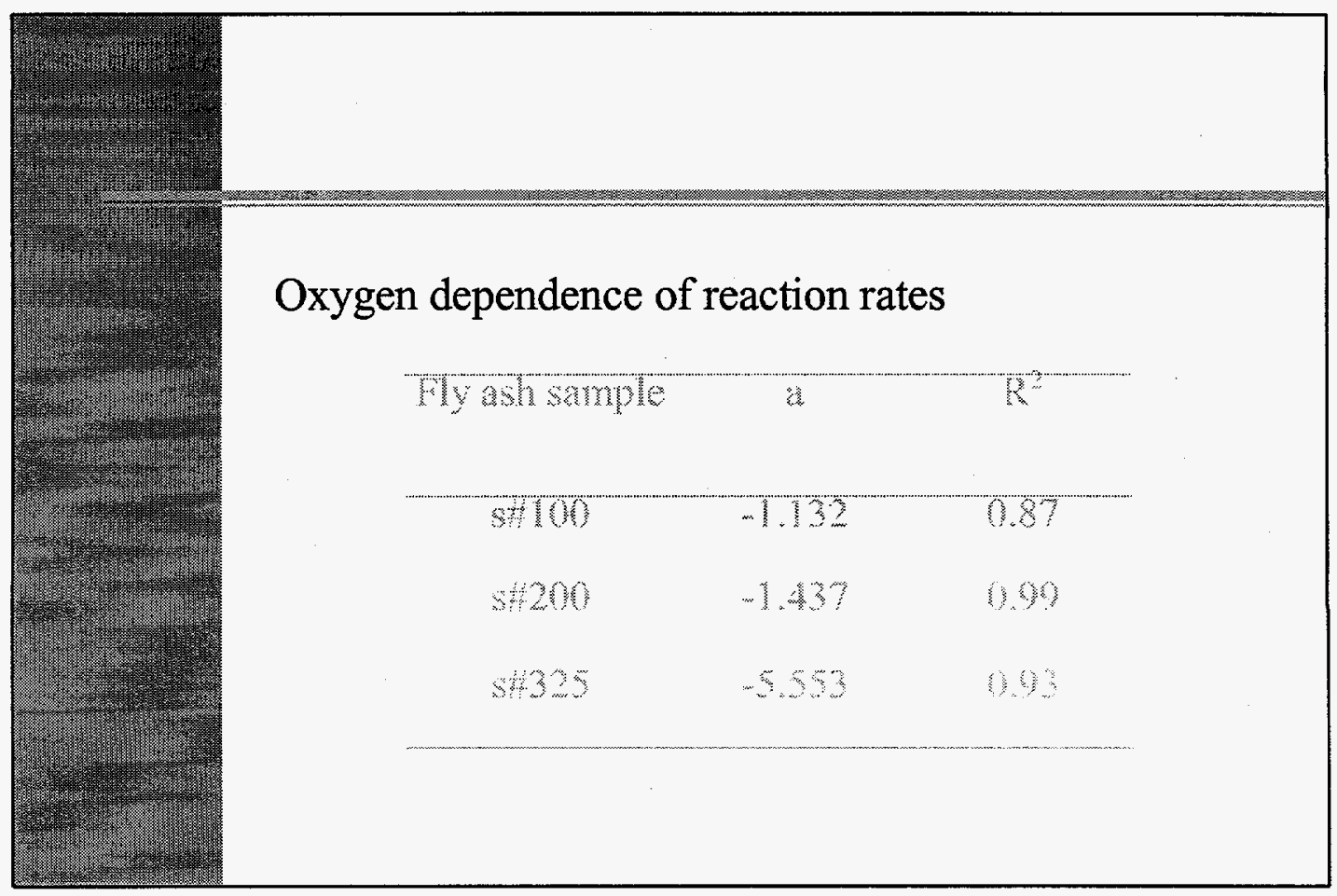




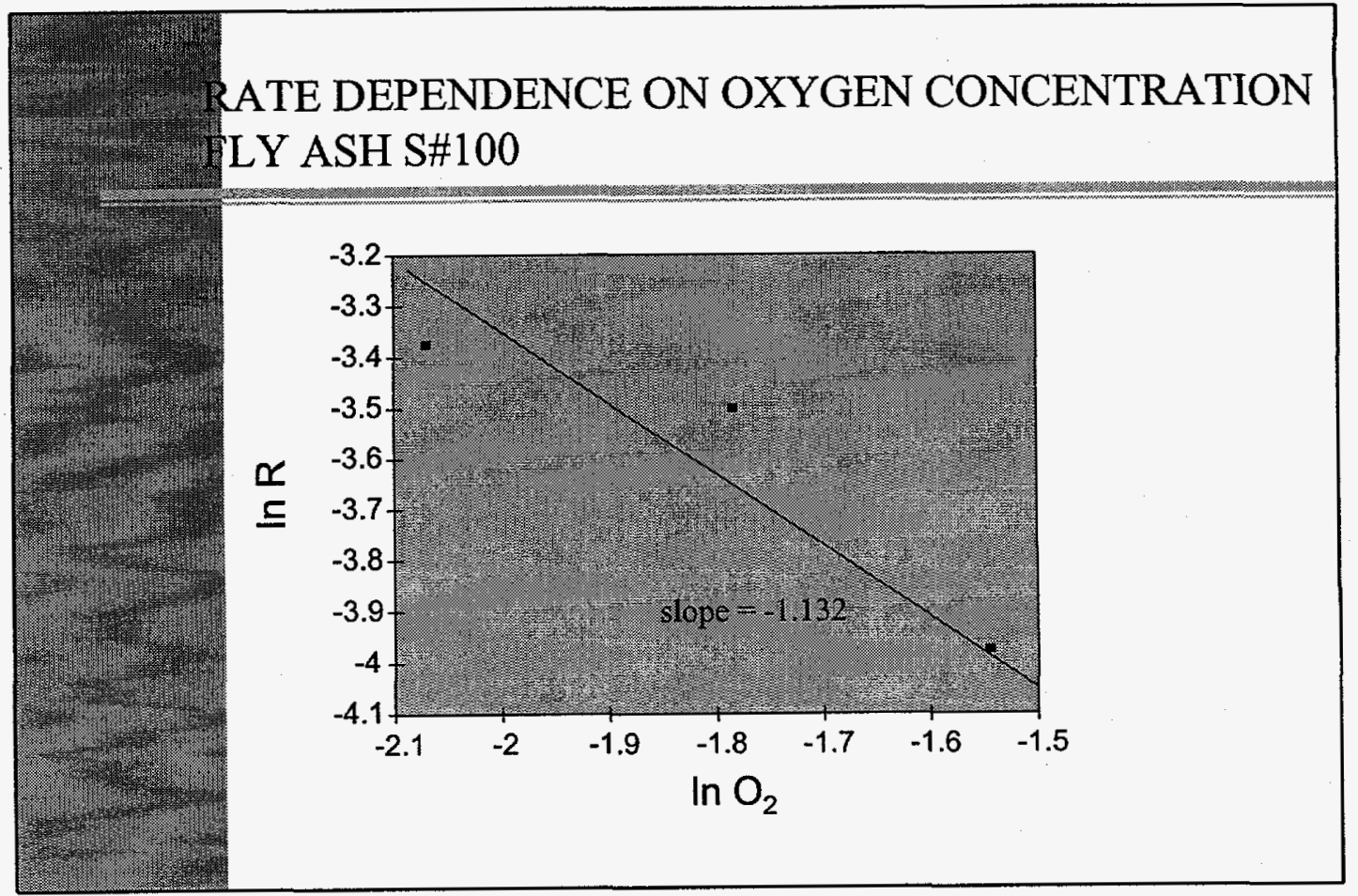




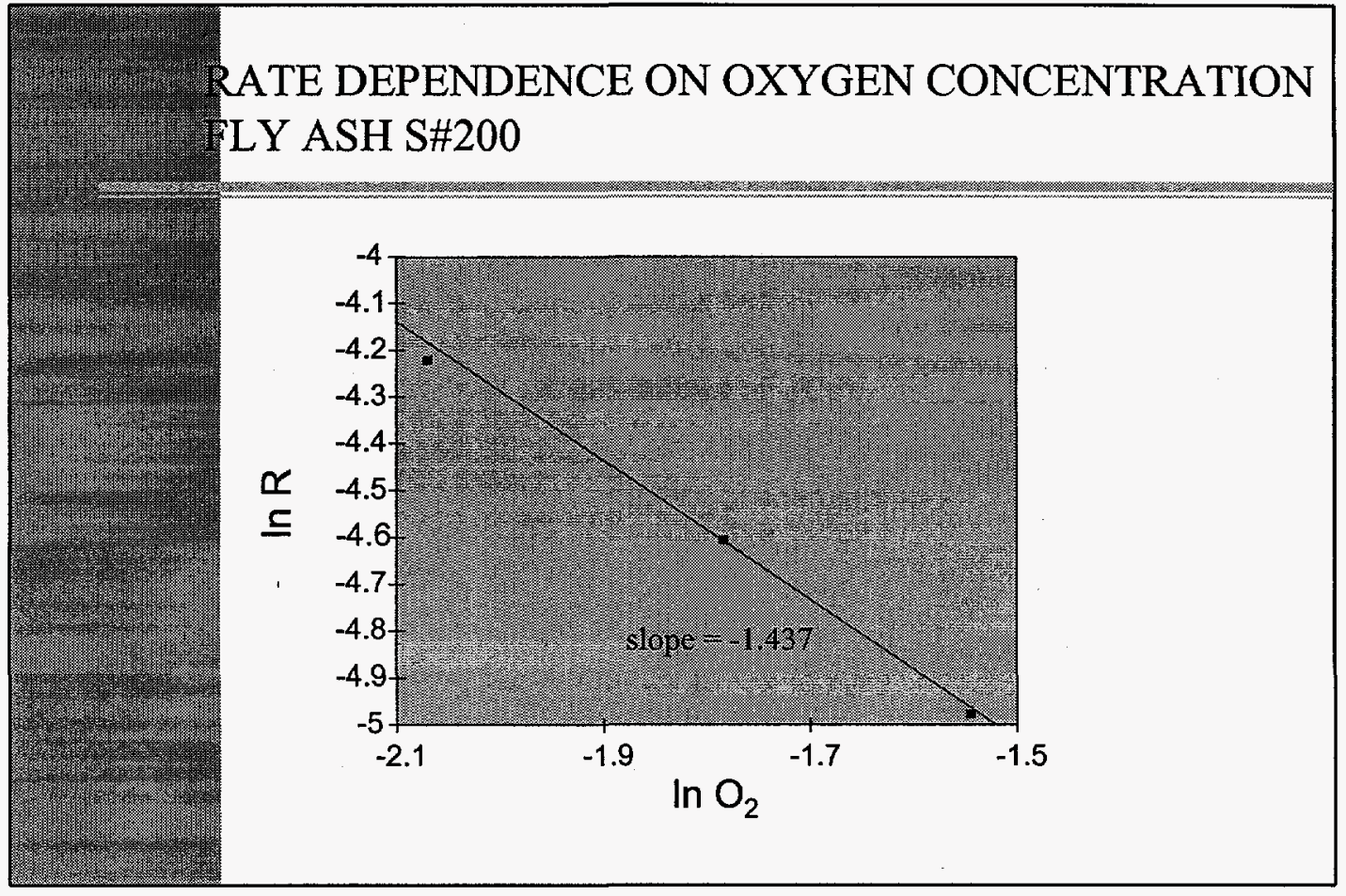




\section{RATE DEPENDENCE ON OXYGEN CONCENTRATION}

LY ASH S\#325

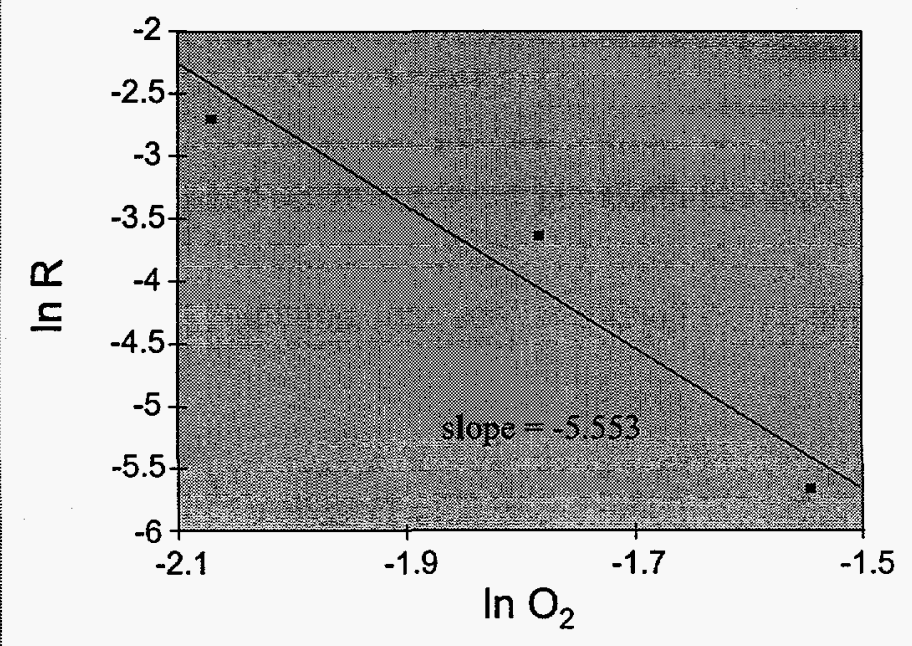




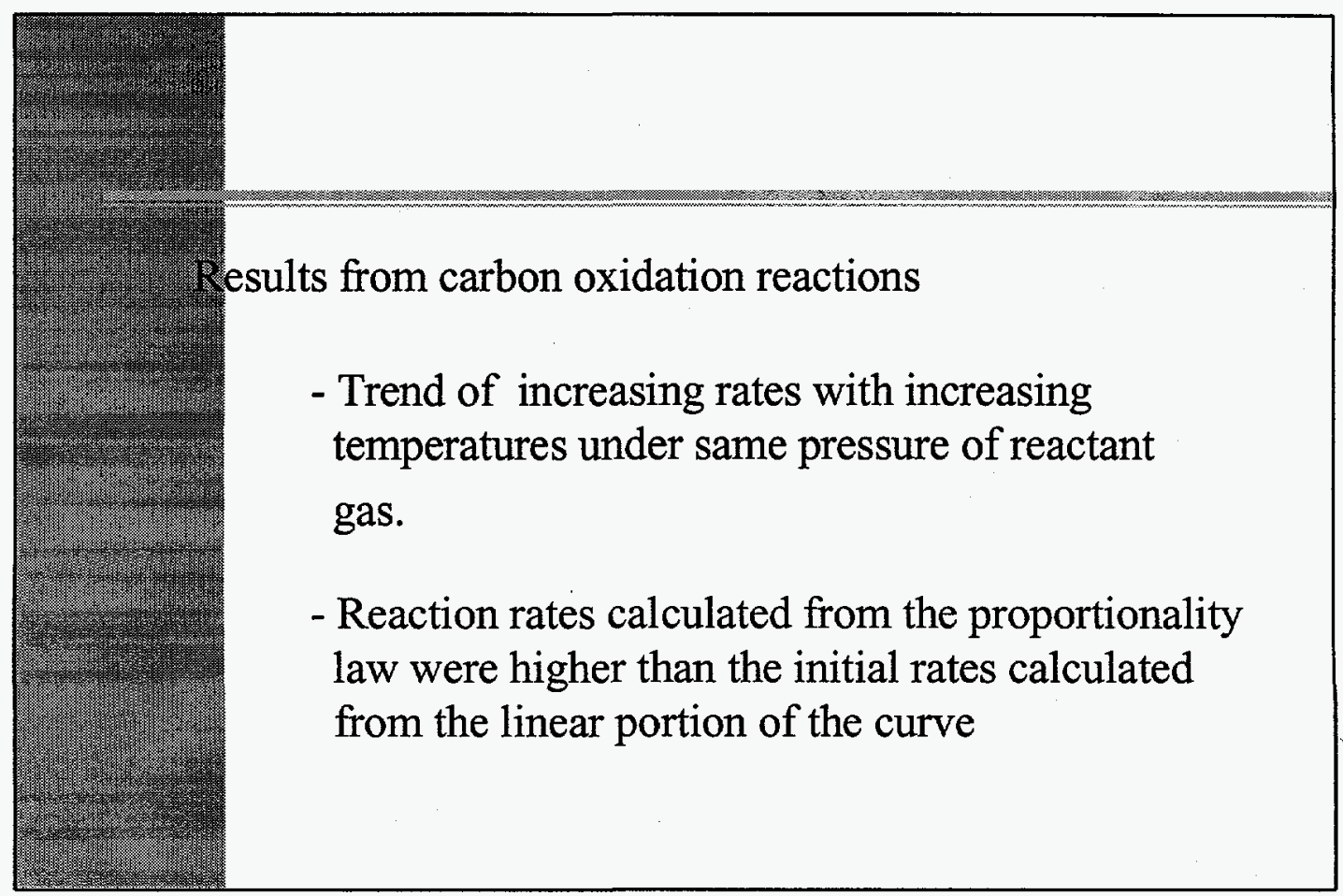




\begin{tabular}{|c|c|}
\hline & \\
\hline & $\begin{array}{c}\text { - Reaction rates represent total weight loss and not } \\
\text { only carbon oxidation }\end{array}$ \\
& $\begin{array}{l}\text { - Evaluation of rate dependence on temperature is not } \\
\text { possible based on data collected }\end{array}$ \\
& $\begin{array}{c}\text { - Trend of increasing rates with decreasing } \\
\text { concentration of reactant gas }\end{array}$ \\
\hline & \\
\hline
\end{tabular}




\section{CONCLUSIONS}

* Surface area analysis reveal that surface area is controlled by carbon content. The higher surface areas in large particles are due to the presence of highly porous carbonaceous particles.

* Reaction rates at temperatures above $550^{\circ} \mathrm{C}$ are not representative of carbon oxidation and, therefore, are not useful in determination of temperature dependence of carbon oxidation in fly ash. 


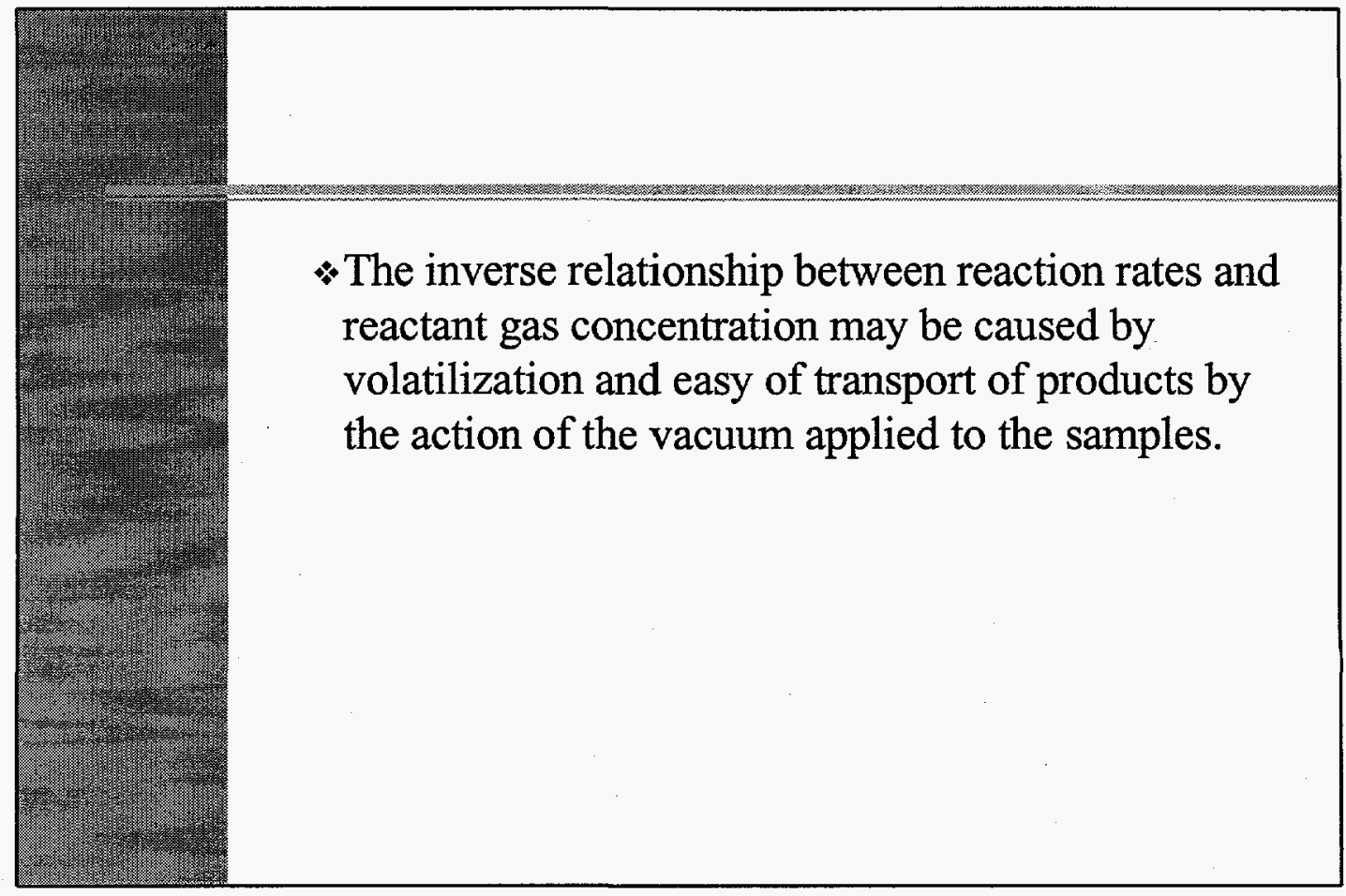




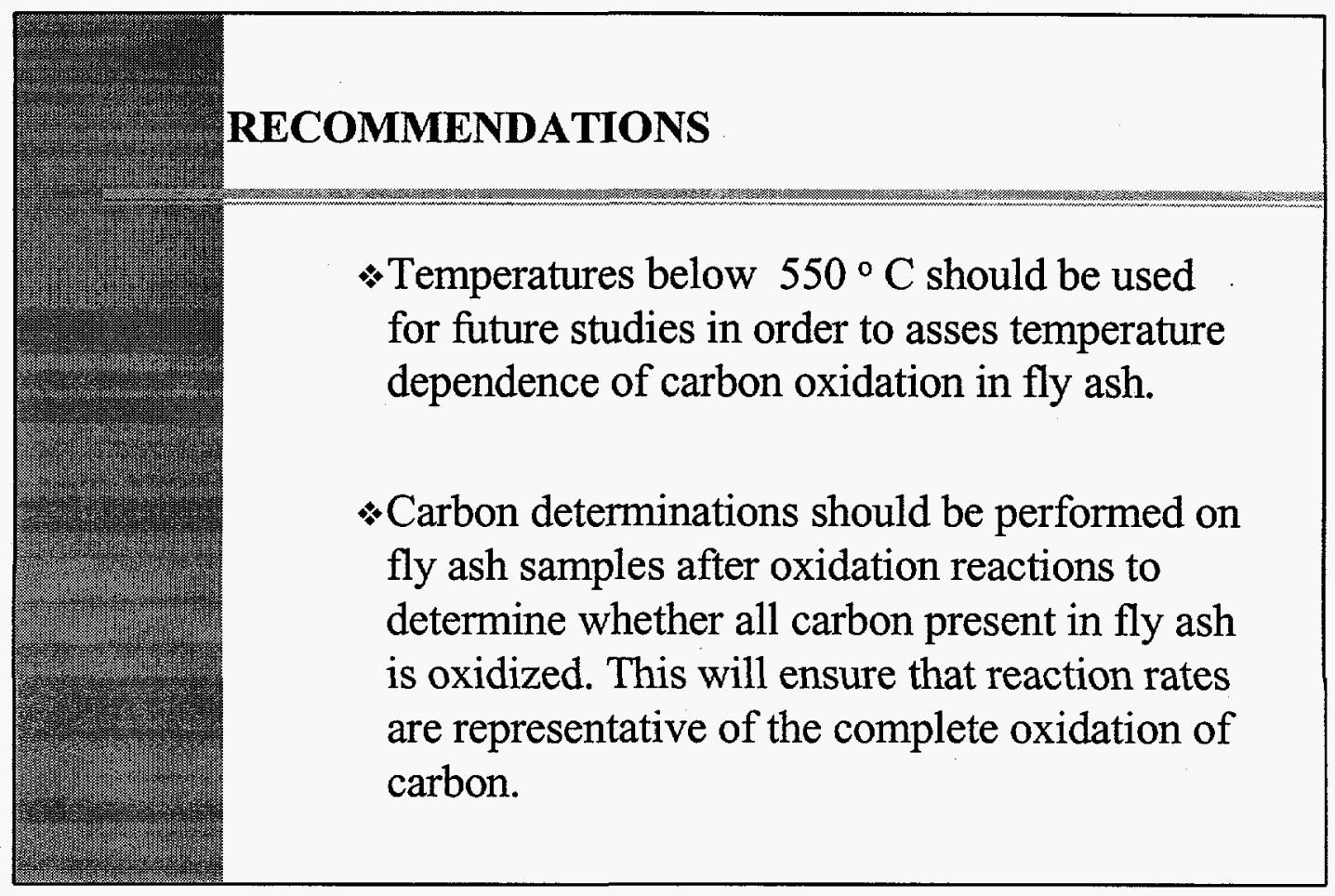




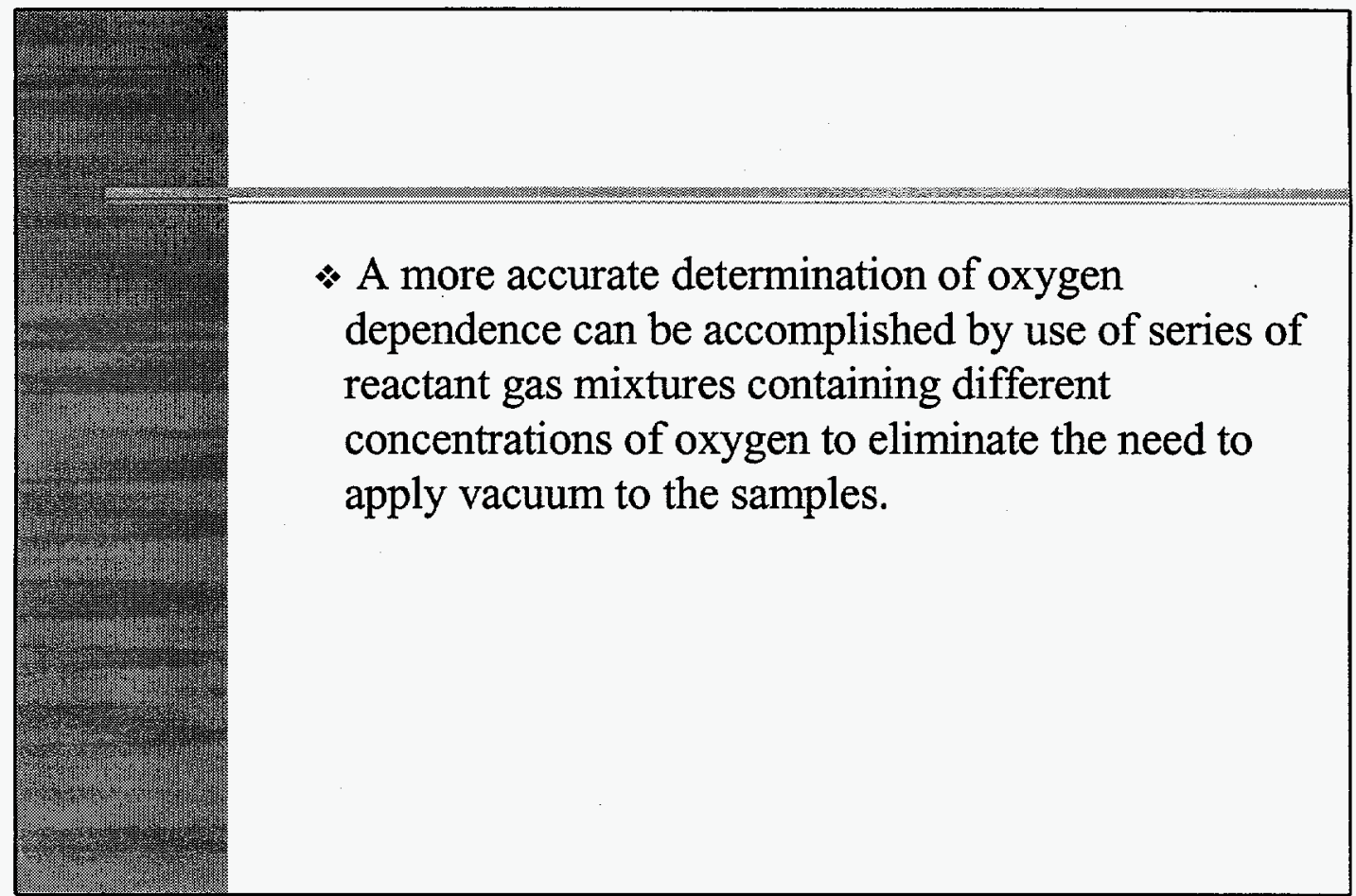




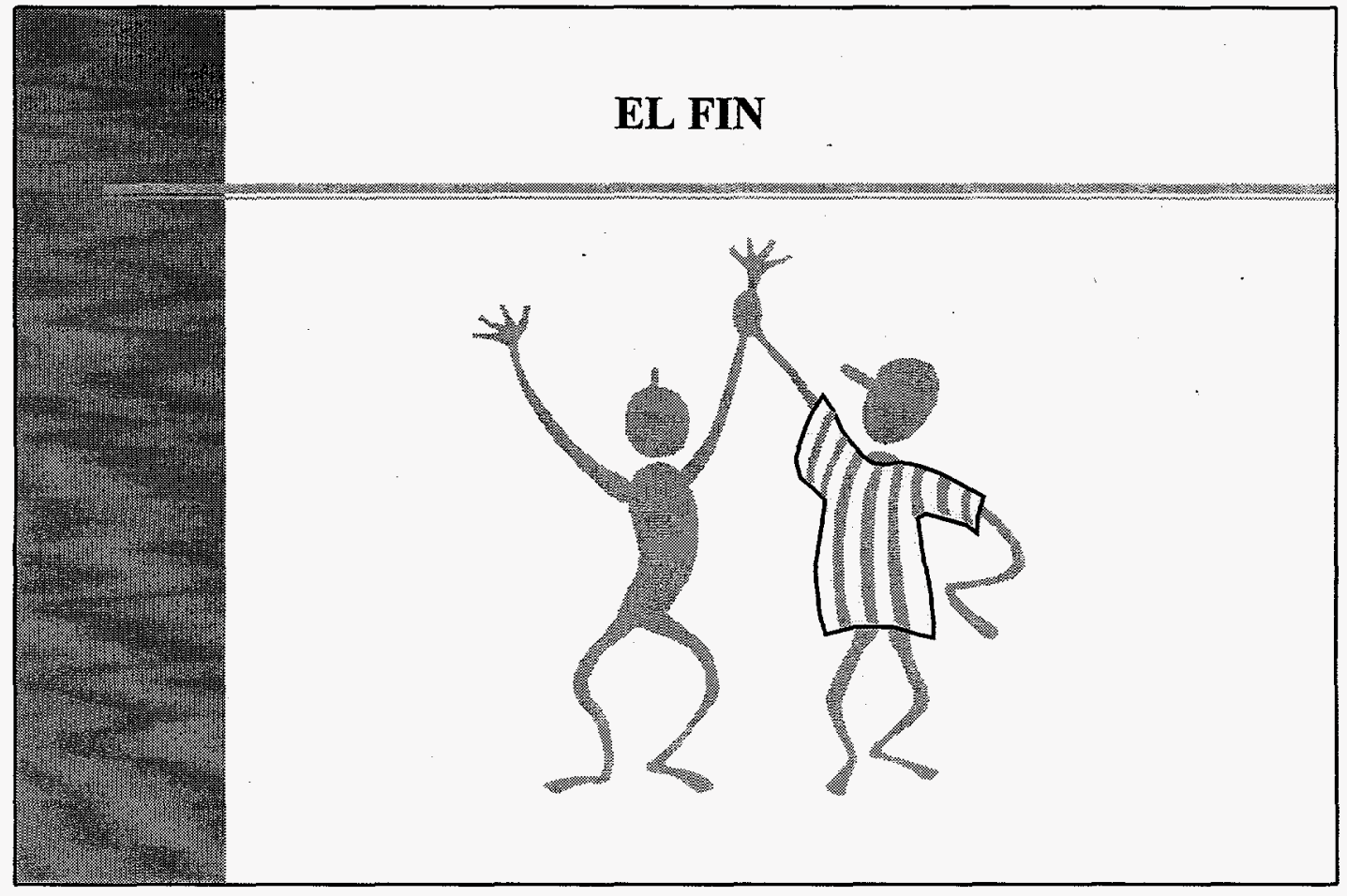

